\title{
The Role of Transposable Elements in Speciation
}

\author{
Antonio Serrato-Capuchina and Daniel R. Matute * \\ Biology Department, Genome Sciences Building, University of North Carolina, Chapel Hill, NC 27514, USA; \\ gaserrat@email.unc.edu \\ * Correspondence: dmatute@email.unc.edu
}

Received: 30 January 2018; Accepted: 26 April 2018; Published: 15 May 2018

\begin{abstract}
Understanding the phenotypic and molecular mechanisms that contribute to genetic diversity between and within species is fundamental in studying the evolution of species. In particular, identifying the interspecific differences that lead to the reduction or even cessation of gene flow between nascent species is one of the main goals of speciation genetic research. Transposable elements (TEs) are DNA sequences with the ability to move within genomes. TEs are ubiquitous throughout eukaryotic genomes and have been shown to alter regulatory networks, gene expression, and to rearrange genomes as a result of their transposition. However, no systematic effort has evaluated the role of TEs in speciation. We compiled the evidence for TEs as potential causes of reproductive isolation across a diversity of taxa. We find that TEs are often associated with hybrid defects that might preclude the fusion between species, but that the involvement of TEs in other barriers to gene flow different from postzygotic isolation is still relatively unknown. Finally, we list a series of guides and research avenues to disentangle the effects of TEs on the origin of new species.
\end{abstract}

Keywords: speciation; transposable elements; reproductive isolation

\section{Introduction}

Speciation is the evolutionary process by which one lineage splits into two reproductively isolated groups of organisms [1]. One of the central goals of speciation research is to understand the processes that drive the evolution of reproductive isolation (RI) between species [2-6]. Significant strides have been made towards identifying barriers that generate RI between species [1,7], the processes underlying their evolution [2,3,8-11], and the rate at which they evolve during speciation [4,5,12-15]. Even though some progress has been made in identifying genes and loci associated with RI, few studies have explored the evolutionary processes that produced these barriers. Because of this, there is not yet a consensus as to what types of mutations or which mechanisms are typically involved in speciation or RI.

There are two broad approaches to identify the genetic underpinnings of RI. First, if crosses can be made, one can genetically map the loci underlying RI between organisms. Such studies can establish the genetic changes that maintain species identity and, if divergence is recent, potentially reveal the molecular changes that were initially involved in speciation. This approach is particularly informative when coupled with closely related organisms at different stages of reduced gene exchange $[1,16,17]$. An alternative approach is to assess whether a particular type of molecular change is commonly associated with isolation between genotypes. If a barrier to gene flow is commonly caused by a certain type of molecular change, then one can argue that that molecular change is important in either the origin of new species or the persistence of them when they face the possibility of collapse through gene flow. This approach has, for example, revealed that chromosomal inversions are commonly associated with the suppression of recombination and frequently harbor gene combinations involved in isolation between species [18,19] (reviewed in [20]). However, this approach has rarely been used to understand 
the impact of other molecular changes on RI. Here we highlight transposable elements as recurring agents that underlie a variety of manifestations of RI, which suggests they should be explored across various taxa in order to better understand their mechanistic and evolutionary contributions.

Transposable elements (TEs) are DNA sequences able to copy and insert themselves throughout the genome. TEs represent up to $80 \%$ of nuclear DNA in plants, $3-20 \%$ in fungi, and $3-52 \%$ in metazoans [21-23]. TEs are classified according to the mechanism they use to transpose. Class I elements require an RNA intermediate in order to integrate/duplicate themselves within a genome, while Class II elements act without an intermediate through a cut-and-paste mechanism that replicates its DNA directly to DNA as it mobilizes (Figure 1). A full classification of TEs is shown in Table 1. Interestingly, the predominant class of TEs can vary greatly between taxa [24-28] and species, and their genomic frequency, location, and activity levels can vary greatly even at the population level. TEs were described for the first time in maize by Barbara McClintock in 1950 [29] where they lead to somatic mutations affecting various phenotypes/genes depending on their chromosomal location and transposition time. The insertion of a TE can disrupt the coding or regulatory sequences of genes, which can cause deleterious effects by the modifying or eliminating a gene's expression [30-34]. TEs are ubiquitous throughout nature [35-37] and their effect on their hosts' fitness is generally considered to be deleterious; TEs are commonly considered selfish elements. However, gene disruptions are not the only consequence of TEs as they transpose throughout the genome. TEs can also cause regulatory changes, genomic expansions, and generate new chromosomal variants through the generation of inversions. Moreover, TEs can produce all of these changes rapidly [38-40] and in response to abiotic stressors-a hypothesis first advanced by McClintock [29]. These changes can provide genetic and phenotypic novelties upon which selection can act [41,42]. Due to their potential to generate novelty when it is needed, some have hypothesized that TEs are maintained in genomes through multilevel selection [43-45].

\section{CLASS 1 - RETROTRANSPOSONS}

\section{CLASS 2 - DNA TRANSPOSONS}

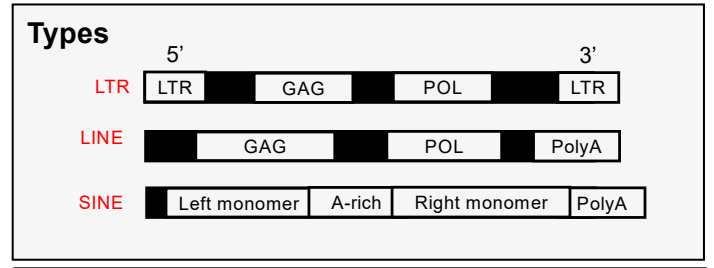

Copy and Paste mechanism
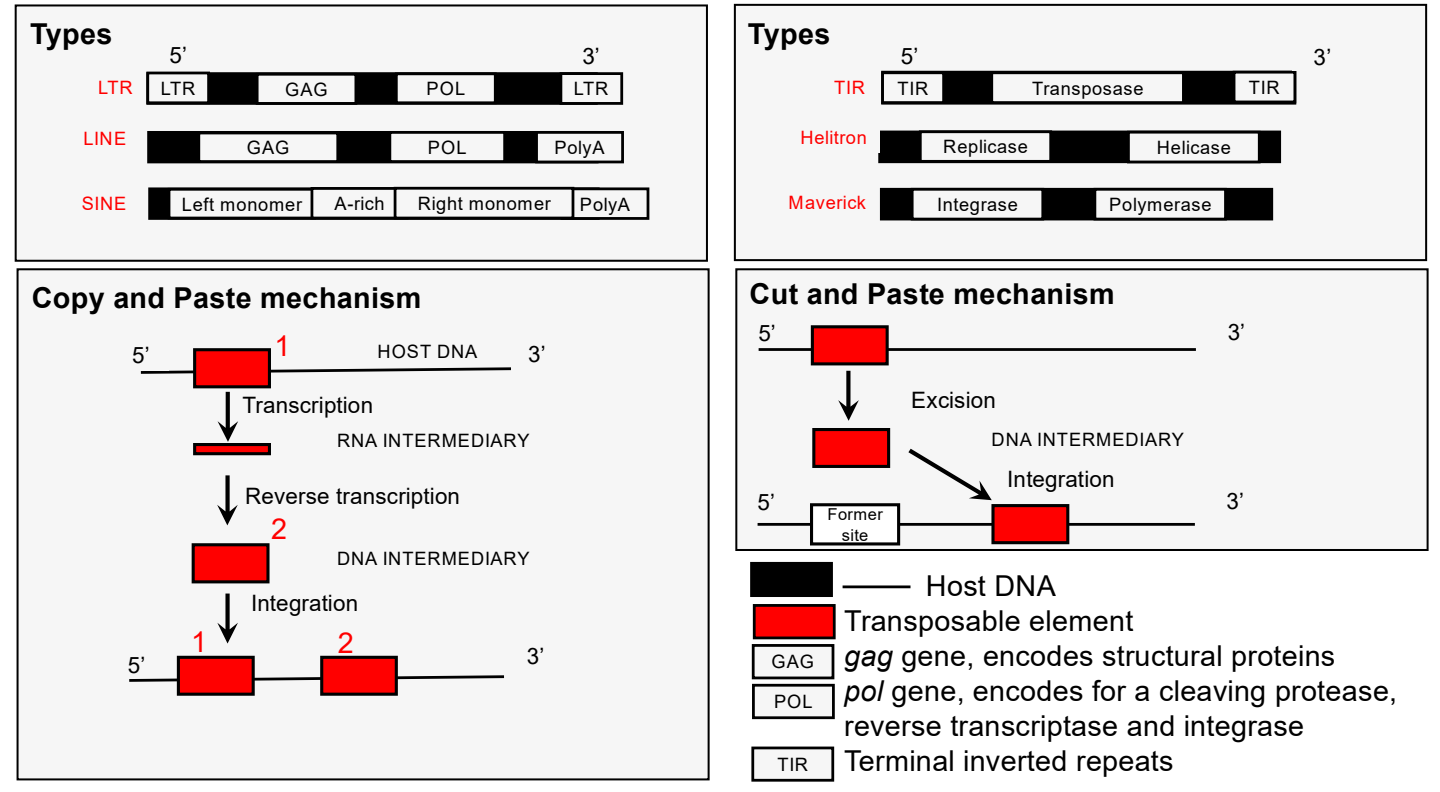

Figure 1. A graphical classification of transposable elements (TEs). The left panel shows Class 1 retrotransposons, and the right panel shows Class 2 DNA transposons. The upper panels show three examples of the genetic structure of each of these two classes of elements. The lower panels show the mode of movement (transposition mechanism) of each class. LTR: Long Terminal Repeats; LINE: Long interspersed nuclear elements; SINE: Short interspersed elements. 
Table 1. A classification of the different types of transposable elements.

\begin{tabular}{|c|c|c|c|c|c|c|}
\hline Type & Name & Activity & $\begin{array}{c}\text { Taxonomic } \\
\text { Distribution }\end{array}$ & Insertion Preference & Function/Pathway Influenced & Citations \\
\hline $\begin{array}{l}\text { Retrotransposons } \\
\quad \text { (class } 1 \text { ) }\end{array}$ & & & & & $\begin{array}{l}\text { Replicate through reverse transcription of an } \\
\text { mRNA intermediate, the resulting cDNA } \\
\text { product integrates }\end{array}$ & \\
\hline \multicolumn{7}{|l|}{ Long-tandem repeats } \\
\hline & BEL/Pao-like elements & non-autonomous & Metazoans & Undescribed & $\begin{array}{l}\text { Second most abundant retrotransposon but } \\
\text { very little is known. }\end{array}$ & {$[46,47]$} \\
\hline & DIRS1-like retrotransposons & autonomous & $\begin{array}{l}\text { Common in decapods, } \\
\text { sparse among } \\
\text { other Eukaryotes } \\
\end{array}$ & $\begin{array}{l}\text { Preferentially integrates into other } \\
\text { DIRS-1 sequences and GTT sequences }\end{array}$ & Undescribed & {$[48,49]$} \\
\hline & Ty1/copia & autonomous & Eukaryotes & $\begin{array}{l}\text { Preference towards upstream region of } \\
\text { RNA Pol III, near tRNA genes }\end{array}$ & $\begin{array}{l}\text { Mutational agent and can mediate genome } \\
\text { rearrangement through recombination. }\end{array}$ & {$[50,51]$} \\
\hline & Ty3/gypsy & autonomous & Eukaryotes & $\begin{array}{l}\text { Upstream of RNA polymerase III } \\
\text { transcription, near tRNA genes }\end{array}$ & $\begin{array}{l}\text { Mutational agent and can mediate genome } \\
\text { rearrangement through recombination. }\end{array}$ & [50] \\
\hline & Ty5 & non-autonomous & Fungi & $\begin{array}{l}\text { Integrates near areas of silent chromatin } \\
\text { at the telomeres and mating loci }\end{array}$ & An increase in recombination at insertion points & [52] \\
\hline \multicolumn{7}{|l|}{ Non-LTR } \\
\hline & Alu & non-autonomous & Primate specific & $\begin{array}{l}\text { Fixed at C-terminus of Human HPK1 } \\
\text { and throughout genome }\end{array}$ & $\begin{array}{l}\text { Cause insertion mutations, increase } \\
\text { recombination, change gene expression through } \\
\text { gene conversion }\end{array}$ & [53] \\
\hline & $\begin{array}{l}\text { LINE (long interspersed } \\
\text { nuclear elements: Jockey, L1, } \\
\text { L2, R2) }\end{array}$ & autonomous & Eukaryotes & $\begin{array}{l}\mathrm{R} 2 \text { inserts into } 28 \mathrm{~S} \text { ribosomal DNA } \\
\text { genes but has a strong bias against } \\
\text { previous } \mathrm{R} 2 \text { insertions. }\end{array}$ & $\begin{array}{l}\text { Encodes proteins responsible for packing of } \\
\text { RNA transcript and a polymerase that enables } \\
\text { reverse transcription, with an endonuclease } \\
\text { subsequently integrating it into the genome. }\end{array}$ & [54] \\
\hline & Penelope & autonomous & $\begin{array}{l}\text { Metazoans, } \\
\text { rare in Plants }\end{array}$ & $\begin{array}{c}\text { Insertions of element have been linked } \\
\text { to breakpoints in inversions within } \\
\text { D. virilis }\end{array}$ & $\begin{array}{l}\text { Element that underlies hybrid dysgenesis in } \\
\text { D. virillis. }\end{array}$ & {$[55,56]$} \\
\hline & RTE (RNA transport element) & non-autonomous & Metazoans & Do not appear to be sequence specific & $\begin{array}{l}\text { Upon insertion has been shown to result in } \\
\text { target site duplications }\end{array}$ & [57-59] \\
\hline & $\begin{array}{l}\text { SINE (short interspersed } \\
\text { nuclear element) }\end{array}$ & non-autonomous & $\begin{array}{l}\text { Plants, metazoans, } \\
\text { fungi }\end{array}$ & $\begin{array}{l}\text { Bias against insertion in intronic splice } \\
\text { sites and preferentially inserts into the } 3^{\prime} \\
\text { region of introns }\end{array}$ & $\begin{array}{l}\text { Shown to control mRNA production and } \\
\text { repress transcription of protein coding genes }\end{array}$ & {$[60,61]$} \\
\hline & VIPER/Ngaro & autonomous & Metazoans, fungi & Undescribed & Undescribed & [62] \\
\hline
\end{tabular}


Table 1. Cont

\begin{tabular}{|c|c|c|c|c|c|c|}
\hline Type & Name & Activity & $\begin{array}{c}\text { Taxonomic } \\
\text { Distribution }\end{array}$ & Insertion Preference & Function/Pathway Influenced & Citations \\
\hline \multirow[t]{15}{*}{ Transposons (class 2) } & & & & & Replicate through a DNA intermediate & \\
\hline & CACTA & autonomous & Plants & Located near centromere & $\begin{array}{l}\text { Results in increased methylation and structural } \\
\text { changes between genetic orthologs }\end{array}$ & [63] \\
\hline & Crypton & autonomous & Fungi, arthropods & Unknown & $\begin{array}{l}\text { Crypton-derived genes function as } \\
\text { transcriptional regulators }\end{array}$ & [64] \\
\hline & Helitron & autonomous & $\begin{array}{l}\text { Plants, metazoans, } \\
\text { fungi }\end{array}$ & $\begin{array}{l}\text { Preferentially inserts in gene-rich } \\
\text { regions }\end{array}$ & $\begin{array}{l}\text { Ability to capture gene sequences, including } \\
\text { introns. }\end{array}$ & [65] \\
\hline & hobo & autonomous & Arthropods & $\begin{array}{l}\text { Biased towards areas with high } \\
\text { recombination rate }\end{array}$ & Can mediate recombination and inversions & {$[66-69]$} \\
\hline & I-element & autonomous & Plants, metazoans & $\begin{array}{l}\text { Located near centromere } \\
\text { heterochromatin }\end{array}$ & $\begin{array}{l}\text { Transpose in germline at a high rate and are } \\
\text { repressed maternally }\end{array}$ & {$[70,71]$} \\
\hline & Mariner/Tc1 & autonomous & All groups & Associated with heterochromatin & $\begin{array}{c}\text { Provide a hotspot of recombination in } \\
\text { Drosophila females }\end{array}$ & [62,72-74] \\
\hline & Mavericks/Polinton & autonomous & $\begin{array}{l}\text { Eukaryotes, some } \\
\text { prokaryotes }\end{array}$ & Unknown & $\begin{array}{l}\text { Retrovirus-like and codes its own DNA } \\
\text { polymerase }\end{array}$ & {$[75,76]$} \\
\hline & Mutator & autonomous & Plants & $\begin{array}{l}\text { Insertions concentrate in epigenetically } \\
\text { marked open chromatin }\end{array}$ & $\begin{array}{l}\text { Insertion sites are correlated with } \\
\text { recombination rates }\end{array}$ & [77] \\
\hline & P-element & autonomous & Plants, metazoans & $\begin{array}{l}\text { Insert at random with a preference for } 5^{\prime} \\
\text { untranslated regions }\end{array}$ & $\begin{array}{l}\text { Underlies hybrid dysgenesis and greatly } \\
\text { increases mutation rate }\end{array}$ & [78-80] \\
\hline & PIF-Harbinger & autonomous & Plants & Target site preference for TAA & $\begin{array}{l}\text { Insertion into regulatory genes resulted in } \\
\text { pigmentation changes in maize }\end{array}$ & [81] \\
\hline & piggyBac & autonomous & Metazoans & Throughout the genome & Acts as an insertional mutagen. & {$[82,83]$} \\
\hline & pogo & autonomous & Metazoans & $\begin{array}{l}\text { Likely to insert in regions with low } \\
\text { denaturation temperature }\end{array}$ & Often leads to deletions & {$[84,85]$} \\
\hline & Rag-like & autonomous & Metazoans & Undescribed & $\begin{array}{l}\text { Linked to recombination and affects immune } \\
\text { system response }\end{array}$ & {$[86,87]$} \\
\hline & Transib & autonomous & Eukaryotes & Undescribed & May underlie the development of new genes & {$[88,89]$} \\
\hline
\end{tabular}


Thus, TEs are diverse and pervasive components of eukaryotic genomes that have the potential to impact rates of diversification and adaptation. TEs have also long been known to cause RI between genotypes (e.g., [78]). However, the role of TEs as a molecular mechanism capable of directly mediating the origin of new species remains underexplored experimentally.

The idea of selfish genetic elements and their involvement in the formation of new species has been latent in speciation genetics for years [90,91]. RI due to intragenomic conflict (i.e., conflictual speciation, reviewed in [92]) seems to be common but until recently was thought to be rare. Meiotic drive, endosymbionts, and maternal effects have all been implicated as potential sources of RI [1], and theoretical models have examined what role they may play in speciation $[93,94]$. Yet, the role of TEs in the initiation of the speciation process and in maintaining species has only rarely been experimentally studied. In this review, we highlight research that emphasizes TEs as important agents involved in the origin and persistence of species, with a focus the evidence for how TEs contribute to contemporary RI. We also propose future directions and questions that need to be addressed in order to understand whether transposable elements are involved in speciation, in the maintenance of species by generating reproductive isolation, and whether they cause distinct macroevolutionary dynamics.

\section{Transposable Elements and Reproductive Isolation}

Traits involved in keeping species apart can be classified depending on when they occur in the reproductive cycle. Premating barriers include ecological and behavioral traits that reduce the likelihood that two individuals will mate and include habitat isolation and mating choice. Post-mating-prezygotic barriers involve interactions between gametes and include sperm/pollen-egg incompatibility. Finally, postzygotic barriers arise after fertilization has occurred, and include various forms of fitness reductions in hybrids $[1,3,95]$. The genetic basis of prezygotic and postzygotic reproductive isolating mechanisms has been studied in varying degrees (reviewed in [1,95]), and a few studies have examined their connection to TE transposition (Table 2). In the following sections, we compile the cases for which TEs have been found to affect a trait potentially involved in RI, in an effort to emphasize their potential role as agents involved in various forms of reproductive isolation.

\subsection{Premating Isolation I: Transposable Elements and Ecological Isolation}

TEs have been hypothesized to promote local adaptation and enable the invasion of new habitats [96]. The initial colonization of a new environment is often accompanied by a reduction in genetic diversity as a result of genomic bottlenecks or founder effects. This hypothesis posits that by rapidly creating new genetic diversity, the transposition of TEs might help populations adapt to their new environment. Encountering a new environment is frequently stressful, and since TEs can be induced by stress TEs could facilitate an increase in genetic diversity exactly when it is needed [97-99]. The genomic shock model proposed by McClintock [29] that TEs mobilize in response to environmental challenges has been supported by many studies across multiple taxonomic groups [94,100,101]. New environments can select for different traits, and if these traits are associated with assortative mating (i.e., dual traits due to pleiotropy; [102,103]), then RI can evolve through divergent selection [104]. Therefore, we hypothesize that TEs could frequently underlie ecological adaptation and perhaps ultimately, speciation. A roadmap to assess whether local adaptation is commonly caused by TEs has been proposed elsewhere [96]. Notably, methods to detect TEs have evolved over the last five years and a fine scale dissection of the identity of the TEs in a genome and their copy-number throughout the genome is now feasible (Table 3), facilitating population level analysis. To examine evidence for our hypothesis, we focus on phenotypes that might lead to premating isolation and for which TEs have been shown to cause phenotypic differences.

Flowering time: Differences in flowering time are a common barrier to gene flow in angiosperms [105]. The mode of action is simple: differences in flowering time lead to RI between genotypes as the gametes of the two genotypes show a reduced probability of encountering each other. Additionally, changes in flowering time have several downstream effects that can further reduce the possibility of gene flow [106]. Besides the lack of contact of gametes due to the temporal differences, 
differing flowering time might also lead to differences in pollinators and thus fosters even stronger isolation than that caused by temporal differences alone.

Table 2. A summary of reproductive isolating barriers for which TEs have been invoked as a potential cause. A full description of the involvement of TEs is presented in the text. Stars represent cases that remain suggestive but for which more evidence is required (see text).

\begin{tabular}{ccc}
\hline Type of Reproductive Isolation & TE-Mediated Phenotype & Examples and References \\
\hline \multirow{2}{*}{ Premating isolation } & Adaptation to new habitats. & Flowering time [63,107] Host specificity [108,109] \\
\cline { 2 - 3 } & $\begin{array}{c}\text { Insertions at loci that control } \\
\text { self-compatibility. }\end{array}$ & $\begin{array}{c}\text { Shift of reproductive strategies lead to reproductive } \\
\text { isolation [110,111] TE movement can lead to gene } \\
\text { movement and aneuploidy in hybrids [112] }\end{array}$ \\
\cline { 2 - 3 } & $\begin{array}{c}\text { Changes in traits involved in } \\
\text { recognition of conspecifics. }\end{array}$ & Mating song frequency between sibling species [113] \\
\cline { 2 - 3 } Postzygotic isolation & $\begin{array}{c}\text { Changes in genome structure. } \\
\text { Hybrid sterility as a result of } \\
\text { reactivated transposition. }\end{array}$ & TE-induced chromosomal inversions [114,115] \\
\cline { 2 - 3 } & $\begin{array}{c}\text { Misregulation of TEs leading to } \\
\text { hybrid inviability }\end{array}$ & Hybrid dysgenesis [55,69,116,117] \\
\hline
\end{tabular}

Table 3. Computational methods to detect transposable elements using genomic data.

\begin{tabular}{cccc}
\hline TE Detection Tool & Year & Language & Reference \\
\hline MELT & 2017 & Java & {$[121]$} \\
IT IS & 2015 & Perl & {$[122]$} \\
Jitterbug & 2015 & Python & {$[123]$} \\
DD_DETECTION & 2015 & C++ & {$[124]$} \\
TIDAL & 2015 & Perl, R & {$[125]$} \\
Mobster & 2014 & Perl & {$[126]$} \\
Tangram & 2014 & Java & {$[127]$} \\
T-lex2 & 2014 & Perl & {$[128]$} \\
TIF & 2014 & Perl & {$[129]$} \\
TranspoSeq & 2014 & Java, R & {$[130]$} \\
TraFiC & 2014 & Perl & {$[131]$} \\
TIGRA & 2014 & C++ & {$[132]$} \\
TE-Tracker & 2014 & Perl & {$[133]$} \\
GRIPper & 2013 & Python & {$[134]$} \\
RelocaTE & 2013 & Perl & {$[135]$} \\
Tea & 2012 & R & {$[136]$} \\
ngs_te_mapper & 2012 & R & {$[137]$} \\
TE-Locate & 2012 & Java, Perl & {$[138]$} \\
REPET & 2011 & Python & {$[40]$} \\
VariationHunter & 2010 & C++, Python & {$[139]$} \\
HYDRA-SV & 2010 & C++, Python & {$[140]$} \\
MITE-Hunter & 2010 & Perl & {$[141]$} \\
SeqGrapheR & 2010 & R & {$[142]$} \\
RISCI & 2010 & Perl & {$[143]$} \\
MoDIL & 2009 & Python & {$[144]$} \\
LTRharvest & 2008 & C & {$[145]$} \\
HelitronFinder & 2008 & Perl & {$[146]$} \\
TransposonPSI & 2008 & Perl & {$[147]$} \\
\hline
\end{tabular}

In at least two cases, genetic mapping has revealed TEs underlying the disruption of genes involved in the pathways involved in flowering time and photoperiod.

The vegetative to generative transition 1 ( $V g t, Z m R a p 2.7 .1)$ locus in maize is an upstream $(70 \mathrm{~kb})$ noncoding regulatory element of a repressor of flowering. At $V g t 1$, a miniature inverted repeat transposable element (MITE) insertion into a conserved noncoding sequence was previously found to be highly associated with early flowering in independent studies [148]. The insertion of 
a CACTA-like transposon into the promoter of a second locus, $\mathrm{ZmCCT}$, can suppress its expression through methylation and reduces maize sensitivity to photoperiod [149].

Similarly, in Arabidopsis, a recessive allele at the locus flowering locus C (FLC), is a result of disruptions of the gene by non-autonomous Mutator-like transposons, which ultimately leads to a delay in flower time. This transposon renders FLC subject to repressive chromatin modifications mediated by short interfering RNAs generated from homologous transposable elements in the genome [150].

TEs might play a role in floral induction and development in the rice shoot apex as a portion of them are silenced during floral induction [107]. The exact role these TEs play in floral induction is unknown, but the recurring activation and silencing of particular TEs, in particular Gypsy elements, at specific developmental stages suggests a regulatory overlap in reproductive development and TE produced small interfering RNA (siRNA). The downregulation of some retrotransposons stops them from repressing genes related to their transition into the reproductive phase, essentially activating genes required for flowering.

These examples show that TEs can modify the mean flowering time through a variety of mechanisms (e.g., differential methylation in maize, repression of an intron via siRNA in Arabidopsis). However, to our knowledge, all flowering time mapping cases have been done within species, thus far no case of between species difference in flowering time has been ascribed to TEs. It is worth noting that different molecular mechanisms resulting from TE insertion can produce the same phenotypic outcome. In maize, a TE insertion results in differential methylation in the regulatory region while in Arabidopsis there is repression at an intron through siRNAs. Interspecific differences in flowering time caused by TEs remain unidentified but it seems like a possible cause of isolation.

Habitat isolation: Abiotic factors such as light and water availability can greatly influence the range over which a plant is able to spread, as well as influence the conspecific mates it will encounter. In the extreme, adaptation to a new environment can completely prevent contact with other members of a species, initiating the process of allopatric speciation.

The CACTA-like TE insertion (in the promoter for ZmCCT; [149]) implicated in photoperiod sensitivity in maize, has also facilitated local adaptation to temperate long-day environments. Additionally, variation in drought tolerance has been linked to a TE inserted in the promoter region of ZmNAC111 [149]. This MITE insertion results in histone hypermethylation, which represses the expression of NAC resulting in a higher drought tolerance.

Selection acting across a continuous distribution of habitat preference can lead to RI as a byproduct of local adaptation to changing environmental factors. TEs may have generated the alleles selected during adaptation to temperate climates in Drosophila melanogaster. A study comparing temperature/latitudinal clines along Australia and North America found 10 TEs that show signs of positive selection at their insertion points, resulting in local adaptation $[96,101,151]$. By causing mutations in genes associated with a suite of traits, including circadian rhythm regulation and starvation resistance, several types of TEs (Long terminal repeats (LTRs), Long interspersed nuclear elements-like (LINE-like), and Terminal inverted repeats (TIR)) are thought to underlie the phenotypic differences along the cline. Suggestively, the TEs were more likely to be adaptive in temperate populations compared to tropical populations where they were likely to be neutral [151]. Taken together, these results strongly suggest that alleles generated by TEs were favored during local adaptation.

Host specificity in oomycetes: One of the main mechanisms of RI in plant pathogens is host specificity, which is regulated by the repertoire of effector genes within each pathogen. Effector proteins alter host physiology and allow colonization by individual pathogens [152]. In oomycetes, genomic distribution of TEs is frequently predictive of host specificity [153-155]. For example, the genome of Phytophthora, a major pest of commercial crops, harbors multiple families of retrotransposons (copia, Gypsy/Ty) [108,155-158]. In Phytophthora infestans - the potato blight pathogen-host specificity is regulated in part by RXLR class effectors that enable P. infestans to utilize a host [109]. As in other systems, TE insertion in P. infestans causes epigenetic silencing of both the transposon and nearby genes, resulting in regulatory differences. 
Notably, synthetic chimeras of a short interspersed element (SINE) to an effector gene in P. infestans leads to the silencing of both the introduced fusion and endogenous homologous sequences [109]. This silencing is also likely to occur naturally in the genome of $P$. infestans, as transcriptional inactivation of effectors is known to occur and over half of RXLR effectors are located within $2 \mathrm{~kb}$ of transposon sequences in the $P$. infestans genome. Thus, it is possible that host range in P. infestans was shaped by TEs inserted near these genes. Since mating in oomycetes occurs on host plants, it is plausible that TE insertions that modify host specificity have led to reproductive isolation in P. infestans. However, a systematic exploration of effector genes and their interactions with TEs would be needed to test this hypothesis.

\subsection{Premating Isolation II: Transposable Elements and Sexual Isolation}

Self-incompatibility: Fungi engage in diverse reproductive strategies, which often vary between closely related species [159]. Fungi often employ a mating system whereby the mating type-which is analogous to the sex-of the individual is determined by alternative alleles at one or several loci. In homothallic strains, which can mate with themselves (i.e., are self-compatible (SC)), additional loci generate allelic diversity at the mating type loci by a copy-paste mechanism (e.g., the homothallic switching (HO) endonuclease in Saccharomyces cerevisiae) $[160,161]$. Since single loci can effectively determine whether two individuals can interbreed or not, TEs can mediate transitions from homothallism (SC) to heterothallism (self-incompatible (SI)) in fungi by disrupting these loci. Transitions from self-incompatibility to self-compatibility are associated with speciation events (e.g., [162-164]) because selfing species are effectively isolated from other individuals and species (with the possible exception of somatic fusion; [112,165]).

Retroelements have contributed to the shifts from heterothallic ancestors to homothallic species in the Neurospora genus through mediating translocations at the mating-type (MAT) loci [166]. Retrotransposon insertions in the MAT locus also occur in Blastomyces and might be involved in decreasing the likelihood of recombination between mating types [167]. In other fungi, transposons have been found within or flanking MAT loci (e.g., Neosartorya fischeri [168], Cryptococcus neoformans [110], Paracoccidioides brasiliensis [167,169]), thus potentially providing an avenue for mating type to evolve independently through a rapid TE-induced mechanism. Specifically, in Neurospora, the transposition of nsubGypsy has facilitated the movement of genes neighboring the MAT loci to a different chromosome [165]. Transposition of npanLTR facilitates unequal crossovers between unrelated intergenic regions of opposite mating types, which in turn facilitates the transition into self-crossing species. Phylogenetic studies in Neurospora and Kluyveromyces lactis show multiple transitions from SI to SC species $[166,170]$. Taken together, these studies demonstrate that TEs may frequently be inserted at MAT loci, but it remains to be seen whether these patterns can be extended to other species.

Besides these effects on mating compatibility, genomic rearrangements mediated by transposition can also lead to viability issues in hybrids [171,172]. Barley rusts, Ustilago hordei, show a large increase in TE activity not observed in other closely related species (Ustilago maydis or Sporisorium reilianum), which has also led to both the reorganization of the MAT loci in the former species as well as large chromosomal rearrangements [173]. Few reports have explored a potential causal connection between TE activity and genome reorganization. A systematic assessment of how often TEs are involved in gene movement across chromosomes is sorely needed.

Transposons may also play an important role in transitions to self-compatibility in plants. Solanum, a flowering plant genus that contains tomatoes, consists of SC and (SI) taxa, with multiple transitions from self-incompatibility to self-compatibility [174]. SC taxa are characterized by low levels or no expression of stylar RNase (S-RNAse). The seven SC and the three SI taxa differ in the $5^{\prime}$ coding region of S-RNAse by several point mutations. Additionally, in one of the SI taxa, the source of low S-RNAse levels stems from an insertion of a transposon-like repetitive element. These results show how single-base mutations and the insertion of TEs can result in similar evolutionary outcomes [174].

These results suggest that transitions to self-fertility mediated by TEs might be common in fungi and plants. We hypothesize that since transitions to self-incompatibility have been associated 
with lower speciation rates and higher extinction rates in plants [175-177], TEs might be associated with differential diversification rates (i.e., species selection [178-180] in fungi. A formal test of this hypothesis remains to be performed.

Mating behavior in Drosophila: Behavioral isolation in Drosophila is mediated through a multimodal signaling system that involves cuticular hydrocarbons (CHCs), visual cues, and auditory signals [181-183]. CHCs are waxy compounds that are involved in desiccation protection (e.g., the species pair D. serrata/D. birchii; $[184,185]$ ) in the abdominal cuticle and are often necessary for mate discrimination and in some cases species discrimination [186-189]. Marcillac et al. [190] studied the effects of an insertion of a TE in the desat1 locus and measured two different traits: the expression of $\mathrm{CHCs}$ and the ability of males to discriminate between the sexes. Even though no naturally occurring TEs have been found in the desat1 locus, over 30 TEs have been found $~ 20-50 \mathrm{~kb}$ upstream of the gene [84,191]. desat1 mutants (i.e., with a TE insertion) had lower CHC abundance (reducing the natural sex dimorphism) than lines without the TE. Moreover, mutant males showed poorer discrimination between control males and females suggesting that the TE insertion changed not only the emitted sexual signal but also how that signal is recognized. It remains to be seen if there are naturally occurring transposon-induced mutants in desat1 or any other allele involved in the production of CHCs.

TEs have been conclusively shown to lead to interspecific differences in mating song in some Drosophila. Male flies in the $D$. melanogaster species subgroup produce a courtship song with two components: trains of continuous sinusoidal sound, called sine song, and pulses separated by an interval, called pulse song [27,192]. In the case of the sister species Drosophila simulans and Drosophila mauritiana, two species that diverged within the last 240,000 years [193-195], D. mauritiana males have a higher song frequency than D. simulans males, which in turn affects mating behavior and is a trait used by females to distinguish between conspecific and heterospecific males [196,197]. A retrotransposon, Shellder, has caused the disruption of the slowpoke (slo) locus in D. simulans [113]. The slo gene is expressed broadly in the fly nervous system and influences many locomotor behaviors and the insertion of Shellder leads to alternate splicing of the gene. Shellder insertions are polymorphic in their insertion sites in wild type strains of $D$. simulans and D. mauritiana, which strongly suggests that Shellder is probably propagating actively in Drosophila populations. The retrotransposon insertion seems to be polymorphic within $D$. simulans, which then leads to the question of whether this has led to isolation between different genotypes of $D$. simulans.

\subsection{Transposable Elements and Postzygotic Isolation}

TEs and chromosomal rearrangements: Chromosomal rearrangements are one of the genome features known to affect the likelihood of gene flow between species (extensively reviewed in [19,198-200]). In general terms, theoretical models indicate that chromosomal inversions can preclude gene flow at certain regions of the genome. Multiple empirical examples have shown that chromosome rearrangements can indeed contribute to postzygotic isolating mechanisms [201] and assortative mating [199], particularly when the rearranged regions contain alleles involved in reproduction. An active research program is trying to assess whether TEs can indeed lead to the origination of new chromosomal rearrangements (illustrated in [202] and reviewed in [66,67]). In Drosophila buzzati, the breakpoints of the $2 j$ inversion contain TEs. It has been hypothesized that $2 j$ might have originated by ectopic recombination of the TE at its breakpoints [114]. Even though this inversion has not been formally associated with RI, $2 j$ is involved with differences in life history traits among $D$. buzzatii populations [203,204]. The phenotypic effects of $2 j$ are contingent on genetic background, which suggests epistatic interactions with the rest of the $D$. buzzatii genome $[115,205]$. If TEs commonly induced inversions and other chromosomal aberrations, then TEs might play a role in maintaining species boundaries.

TE reactivation: In animals, fungi and plants, TEs are often targeted and silenced by siRNAs [206]. In plants, siRNAs involved in heterochromatin formation often target TEs and silence them [207]. Unlike animals, where the germ cells are formed early in development, plant germ cells differentiate from somatic cells in the adult and the chromatin remodeling ATPase decrease in DNA methylation 1 (DDM1) is crucial for this process. In Arabidopsis, DDM1 is necessary to silence TE activity [206-209]. Even though TE reactivation and accumulation is restricted to the vegetative nucleus and not the 
sperm cells, TE accumulation in the vegetative nucleus can affect the sperm cells of the pollen and result in heritable changes [206]. In tobacco, just as in Arabidopsis, cytoplasmic connections between sperm cells and the pollen vegetative nucleus have previously been observed $[206,210]$ and might provide a channel for siRNA and facilitate TE silencing. As a result, TE misregulation, which in essence is a hybrid specific defect of the TE-repressor system, might be a potential source of hybrid defects in pollen.

DDM1 is also required to produce hybrid vigor (heterosis; [211]). Arabidopsis F1s between divergent accessions regularly show hybrid vigor in vegetative biomass throughout their lifecycle [212]. However, crosses involving DDM1 loss-of-function mutants do not show heterosis; TEs are extensively expressed, which in turn causes abnormal and expression of genes related to salicylic acid metabolism [213]. Since fitness is so drastically affected by TEs, through either heterosis or hybrid incompatibility, these results might indicate that expression of TEs in hybrids changes their epistatic landscape (in a way that does not occur in pure species) with potentially deleterious effects. The role that DDM1 plays in establishing RI could be tested by mutating $d d m 1$ across multiple plant lineages. The results from such mutagenesis approach will reveal whether this epigenetic regulator of TEs is involved in reproductive isolation in multiple species pairs.

Hybrid breakdown through deregulation of TEs is another postzygotic barrier between species. Lake whitefish lineages have repeatedly colonized postglacial lakes across North America. During these colonizations, a dwarf limnetic species has evolved from a benthic species multiple times. This repeated evolution has led to incomplete RI between the limnetic and benthic lineages $[214,215]$. Although the two lineages can produce viable hybrids, there is significant mortality in all hybrid types and backcrosses regularly show a malformed phenotype. Analysis of the transcriptome of hybrids reveals a 232-fold increase in TE activity in malformed embryos compared to pure crosses. This transcriptome wide deregulation of TEs results in shutdown of vital metabolic pathways drastically reducing the fitness of hybrids [216].

The reactivation of retroelements in hybrids can also lead to changes in chromatin profiles. Interspecific crosses of two Wallaby species, Wallabia bicolor and Macropus eugenii, produce hybrids with autosomes from Macropus eugenii that have a larger centromere $[217,218]$. The extended centromeres differ from those found in either parental species as hybrid centromeres consist primarily of un-methylated retrotransposons. TEs, then, can also affect chromatin structure and chromosomal composition in hybrids. Transpositions resulting from TEs being released from siRNA, epistatic, or epigenetic suppression mechanisms are pervasive across various eukaryotic groups and drastically change the fitness of hybrids.

Hybrid inviability: An extensively studied case of reproductive isolation is the genetic interaction between Hmr, Lhr, and $g f z f$ in $\mathrm{F} 1$ hybrids between D. melanogaster females and D. simulans males. Alleles from these genes genetically interact to cause hybrid lethality between $D$. melanogaster and D. simulans [219-222]. RNA-seq analyses revealed that $\mathrm{Hmr}$ and $\mathrm{Lhr}$ are required to repress transcription from satellite DNAs and many families of TEs in their native hosts [222]. One possible cause of aberrant TE expression in hybrids is altered expression of Piwi-interacting small RNAs (piRNAs), a class of small RNAs that interacts with the Piwi family of Argonaute proteins to control the expression of TEs in the germline [223]. This is because the piRNA population in a host rapidly adapts, within $\sim 6$ generations [224], to the TE content through generation of new piRNA clusters, allowing de novo production of piRNA and other types of small RNAs for silencing of the invading TE $[225,226]$. Overexpression of TEs is frequently found in F1 hybrids, and is often associated with male sterility $[227,228]$. Overall these results suggest that the regulation of TEs might be of importance in maintaining contemporary species boundaries.

Hybrid dysgenesis: Drosophila is arguably one of the premier systems to understand the spread of TEs in animals. At least three families (hobo, $P$-elements, $I$-elements) have been found in D. melanogaster $[68,229,230]$. Of these families, $P$-elements (PEs) have received the most attention, as a result of a suite of defects in F1 hybrids (i.e., hybrid dysgenesis). Hybrid dysgenesis occurs in F1 hybrids from crosses between an 
uninfected female and an infected male [116,117], whereas individuals from the reciprocal cross are fertile. In dysgenic individuals, TEs proliferate and lead to a suite of defects such as chromosomal breakage, germ line cell apoptosis, and an increase in point mutations [78,231-233]. Despite drastic consequences PEs have spread throughout $D$. melanogaster [84,230,234] and D. simulans worldwide [235]. PEs are thought to have originated in the neotropical $D$. willistoni species group $[79,236,237]$. Although mites have been proposed to serve as a vector for PEs, potentially as a byproduct of their syringe-like feeding method [238], the precise mechanisms of this horizontal transfer remain unknown and untested.

The unidirectional development of hybrid dysgenesis between crosses stems from the way that genomes protect themselves the deleterious effects of PE activation. In F1 hybrid females, hybrid dysgenesis is only present in daughters from mothers with no PE and fathers with PEs. Usually the infertility that characterizes hybrid dysgenesis is silenced through piwi-interacting RNA silencing [239-242], which are exclusively maternally inherited. piRNAs seem to be present in all arthropods [243], and in the case of Drosophila piRNAs are cytoplasmatically deposited in embryos from females that contain PEs. Recent work shows that piRNAs are not alone in mitigating PE's effects. PEs in D. melanogaster lead to hybrid sterility when the germoplasm does not carry the molecular machinery to regulate the expansion of PEs through minimizing cell apoptosis by co-opting the use of genomic maintenance genes such as $p 53$ [69].

A similar phenomenon, yet much less studied, occurs in Drosophila virilis [55]. The elements Penelope, Ulysses, Paris and Helena and Telemac have rapidly increased in frequency in natural populations. Experimental injection of Penelope causes germ line mutations as well as the activation of other TEs [55]. Similar to the hybrid dysgenesis phenomenon observed in D. melanogaster, when uninfected females are crossed to infected males, the resulting progeny show a high level of gonadal sterility, chromosomal nondisjunction and rearrangements, male recombination, and the occurrence of multiple visible mutations. There are however, notable differences between these two systems. While in $D$. melanogaster only one family of TEs are activated at once, in the D. virilis dysgenesis, all families are activated simultaneously $[55,244]$. The Penelope family seems to be primarily responsible for the hybrid dysgenesis syndrome of $D$. virilis [55].

If hybrid dysgenesis is a mechanism that can generate RI in populations of the same species, then the molecular machinery that regulates TEs might be important to not only maintain species boundaries at present but also facilitate speciation. This includes an assessment of whether TEs and TE-repressor system act as traditional genetic incompatibilities in hybrids [245]. A valuable research avenue will be to evaluate the effects of PEs in interspecific crosses and whether hybrid dysgenesis is a source of selection for speciation via reinforcement.

Genomic imprinting in endosperm: Maturation of the embryo in angiosperms is contingent on normal development of the endosperm, a tissue that feeds the embryo during seed development $[118,119]$. Allocation of nutrients in the endosperm is consistent with parental conflict theory and excess dosage of paternal alleles promotes larger seeds while an excess of maternal alleles produces small seeds. This tissue is usually triploid and its normal development depends on the proper balance of gene imprinting [119]. Imbalances between paternally and maternally imprinted genes can lead to changes in gene expression through regulatory changes, a phenotype that is commonly aberrant in heterospecific hybrids (e.g., [246,247]).

Arabidopsis arenosa and Arabidopsis thaliana hybrid seeds show an overgrown endosperm and arrested or abnormal embryo development. A. thaliana harbors LTR retrotransposons of the Ty3/Gypsy family, known as Athila. These elements are large, with an internal region up to $10.5 \mathrm{~kb}$ long, flanked by an average of $1.8 \mathrm{~kb}$ LTRs on either side. This internal region produces two proteins: the gag capsid structural protein and pol, which carries the protease, reverse transcriptase and integrase domains essential for element duplication [248,249]. Seed inviability is positively correlated with the relative paternal genome dose, suggesting that maternal genomic excess suppresses incompatibilities in hybrids [246]. Moreover, the maternal genomic contribution (and thus seed viability) is inversely correlated with expression of Athila retrotransposons, expressed mostly from the pericentromeric 
regions. The normally silenced Athila (but not other TEs) is extensively expressed in hybrids. Only the paternal, and not the maternal, copies are expressed in these interspecific hybrids.

The precise reason why TEs are misregulated in hybrids relative to parentals remains unclear and likely varies across species. The interactions between paternally and maternally imprinted genes might lead to changes in silenced regions, which in turn is a common cause of postzygotic isolation in heterospecific crosses. Imprinting in plants is intimately associated with changes to methylation of TEs [120,250], and TE activity is known to alter DNA methylation patterns and gene imprinting in plant genomes [251-253]. Alternative molecular mechanisms-that might act in concert with perturbed imprinting - have also been proposed to account for seed failure, such as poor regulation of TEs by siRNAs in hybrids [254].

A systematic exploration of how often TEs promote post-zygotic isolation remains a promising research avenue to understand the link between TEs and speciation.

\section{Introgression and Transposable Elements}

Introgression, which is defined as the transfer of genetic material between species through the production of fertile interspecific hybrids, has recently been shown to be common across all domains of life $[255,256]$. Understanding what factors allow for gene exchange is crucial to understanding how species-especially nascent ones-persist in cases where they have the chance to interbreed and fuse into a single lineage. The relationship between transposable elements and introgression is multifaceted and includes (i) TE-aided introgression of non TE-DNA and (ii) interspecific transmission TEs alone.

First, TEs might facilitate or hamper introgression of surrounding DNA. Surprisingly, this hypothesis remains untested even though its prediction is straight forward: if TEs increase the likelihood of introgression, then in hybridizing species regions that are TE-rich should show a larger amount of introgression compared to the rest of the genome. If, on the contrary, TEs hamper introgression through selection against regions containing TEs, then TE-rich regions should be refractory to introgression. These two scenarios are illustrated in Figure 2. Even though no systematic study has addressed whether TEs facilitate introgression, there are some indications TEs might be involved in horizontal gene transfer (HGT) $[257,258]$. The coffee berry borer beetle, Hypothenemus hampei [259], and the mustard leaf beetle, Phaedon cochleariae, appear to have acquired the genes necessary for their specialized diet through a HGT from bacteria [260], allowing them to degrade plant cell walls. Interestingly in both cases, the genes acquired by the beetles are flanked by two transposons. The potential role TEs might have played in this transfer remains suggestive but inconclusive.

Introgression might also lead to the transfer of TEs across species boundaries [261,262]. HGT have been linked to speciation events (or at least specialization events) in bacteria, providing novel gene sets that expand host specificity. Horizontal gene transfer regularly acts as a genetic bridge between vastly diverged species $[257,258]$. Horizontal transfers of TEs between angiosperm genomes have been documented in nature [263-265] and experimentally [266]. In Drosophila, HGT seems to have occurred from the willistoni species group to D. melanogaster. The two groups diverged over 50 million years ago and there is no possibility of hybridization [267]. Many other cases of HGT between species (with a rapidly growing list) have also been reported but the precise mechanisms of gene exchange remain largely unknown and might differ between taxa and reproductive strategies $[118,268,269]$. By serving as a pathway to TE acquisition, HGT can result in RI when coupled with the effects of new TEs entering a genome. 


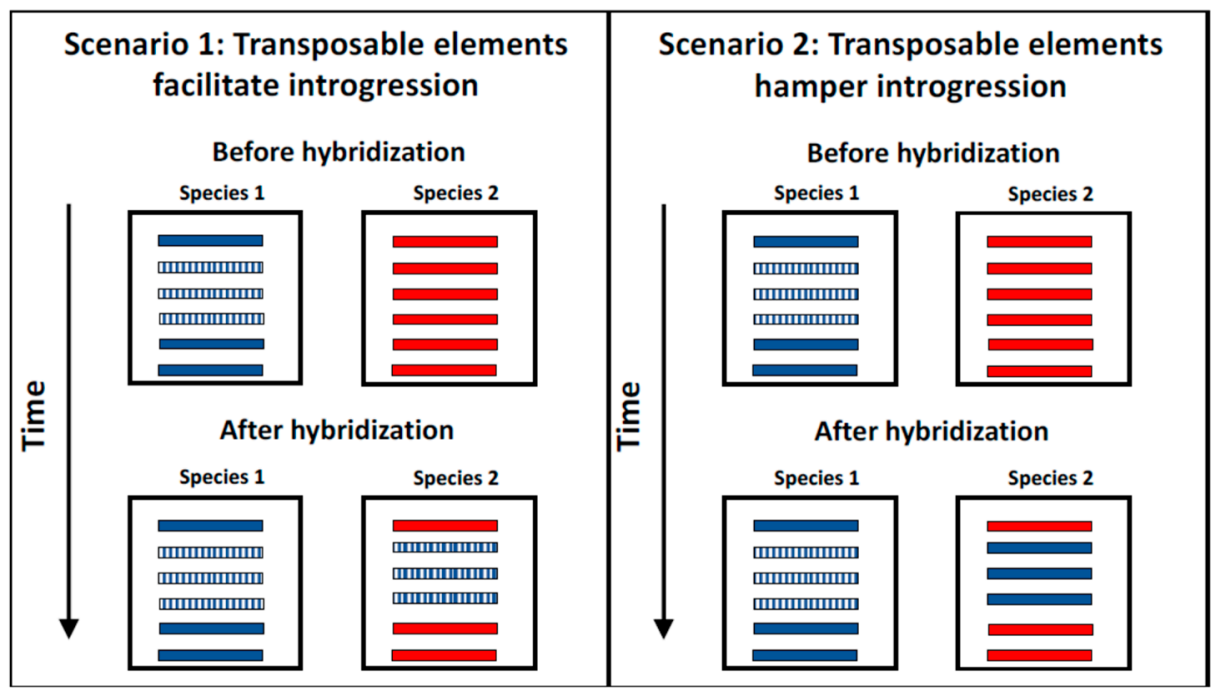

Figure 2. Two possible scenarios that illustrate potential connections between TEs and the likelihood of introgression. Two species are illustrated (blue and red). Stripped bars show chromosomes that contain TEs, while solid bars are chromosomes with no TEs. The left panel (Scenario 1) shows a potential scenario in which TEs facilitate the transfer of a full chromosome. The right panel (Scenario 2) shows a potential scenario in which TEs cannot cross the species boundary and thus chromosomes that harbor them are less likely to be introgressed. For simplicity only one direction of introgression is shown.

The most likely mechanism of transfer of genetic material between closely related species is arguably the production of fertile hybrids with subsequent introgression. Even though it is clear that TEs can be mobilized by HGT, it remains unclear to what extent TE activation can occur through introgression. This question remains largely unexplored both in natural and experimental populations. This scarcity is puzzling because the proposal that introgression mediated by hybridization could lead to transposon introduction and mobilization within the genome of rice is not new (i.e., a genome shock, [270]). Two examples of TE mobilization following introgression stand out. First, recombinant inbred lines produced by hybridizing rice species (cultivar Matsumae and wild rice Zizania latifolia) have shown that the miniature-Ping (mPing) TE together with its putative transposase-encoding partner, Pong, can be mobilized between species [271,272]. Likely, the mobilization of mPing and Pong is a result of introgression-induced malfunction of the established cellular control systems in the rice genome, as their transposition is transitory and rapidly repressed.

The second example comes from experimental hybrid swarms between two divergent species of Drosophila: D. melanogaster and D. simulans. Both species harbor the Bari-I element, a Class II TE with an open reading frame able to encode a polypeptide with 339 amino acids. (The sequence of the putative protein in Bari-I is similar to the transposase of the Tc-1 element of Caernorhabditis elegans, which might in turn suggest HGT across animal orders [273].) In synthetic hybrid swarms using D. simulans C167.4, an unusual line that produces fertile hybrid offspring with D. melanogaster, Bari-I elements, originally from the $D$. melanogaster parent, are maintained in hybrid strains, suggesting that introgression can indeed be a mechanism of transfer of TEs. The element is present across the geographic range of both species and shows such similar sequence that it seems to be transmitted horizontally and not vertically [274].

Introgression of TEs has been hypothesized for Drosophila bifasciata and Drosophila imaii [80], species of the simulans complex [275], species of the groups willistoni (reviewed by [276]), saltans ([277,278]), and the species pair Drosophila serido and D. buzzatii [279]. The main lines of evidence in these studies have been the ability of these species to produce fertile hybrids and the sequence similarity of TEs across species $[72,80,280,281]$. A full and detailed characterization of the rates and nature of introgression awaits 
for most of these groups and should be coming in the near future as TEs will continue to be a focus of research due to their diverse effects across organisms.

\section{Future Directions}

The relationship between TEs and RI is an open field of research that will likely increase in prominence over the next few years. Given the broad range of roles TEs have played in affecting gene exchange between various species, further study is required in order to better understand the extent to which TEs influence evolution and speciation. Box 1 lists focal questions that remained unanswered. These questions fall into three broad categories.

\subsection{Are Transposable Elements a Common Cause of Reproductive Isolation?}

Mapping the precise genetic basis of interspecific differences will reveal what type of mutations and genomic interactions are more likely to cause and maintain interspecific differences and their relative contribution to various forms of RI. This will lead to a better assessment of the relative importance of TEs as a genetic cause of RI. A second line of research will explore the role of TEs in adaptation to the peripheral areas of geographic range of a species. In maize, for example, Mutator TEs are reactivated in response to environmental stress [282], which is most likely to occur at the edge of the optimal range of the species. TE reactivation might induce to genomic changes that in turn lead to RI between peripheral populations in extreme environments and the central populations' (akin to peripatric speciation; $[1,283])$. Moreover, hybrid zones are usually found at the edges of the range of the hybridizing species so the interplay of hybridization and potential activation of TEs due to environmental or competition induced stress should be examined (Questions 1-5 in Box 1).

\subsection{Are Transposable Elements Responsible for Differential Rates of Diversification?}

The broad range of genome sizes across eukaryotes is partially explained by the quantity of repetitive, non-coding DNA-including TEs-interspersed throughout the genome [22,118,284-288]. The consequences of genome expansions are significant and have been linked to the duration of meiosis, ecological distribution, speciation rate, and extinction risk (e.g., [289,290] reviewed in [291]). Genome rearrangements and, in particular, genome duplications have been associated with higher rates of diversification in teleosts [292-294] and angiosperms [295,296]. The reasoning behind why genome duplications lead to an increase in diversification rates remains unclear but generally there are two explanations. First, genome duplication allows for gene subfunctionalization and neofunctionalization that would not be possible in a non-duplicated genome [297-300]. Second, large genomes might simply have the chance to accumulate more hybrid incompatibilities. Only one systematic evaluation of the relationship of genome size and cladogenesis has been performed (for angiosperms) and it found evidence of a positive correlation between overall genome size and rates of speciation [301,302]. Since TEs commonly lead to an increase in genome size, this is consistent with the hypothesis that invasion by TEs can increase the rate of speciation.

An evaluation of this hypothesis has been carried out in haplochromine cichlids. A comparative analysis to determine what traits were correlated with successful adaptive radiations in Lakes Malawi and Victoria found that traits like decoupled pharyngeal jaw and maternal mouth brooding - which have been hypothesized to be key innovations enabling diversification in cichlids-could not account for differences in the rate of diversification in this group. In contrast, increased numbers of SINE insertions preceded the extensive radiations within each lake [303]. These results are consistent with TEs mediating adaptation through either gene disruption or altered methylation patterns near insertion sites. However, determining whether TEs generally lead to increased speciation rates will require a formal macroevolutionary test in which the sample size (i.e., potential radiations caused by TEs) is larger than one [304].

Conversely, TEs could result in increased extinction rates and therefore lead to decreased diversification rates. This is related to an intriguing hypothesis that posits that asexual groups form reciprocally monophyletic clusters (akin to asexual species) rapidly but also disappear rapidly 
due to the proliferation of deleterious transposons inherited from their sexual progenitors that cannot be purged by recombination, leading to extinction [42,305]. (Questions 6-9 in Box 1) Additional studies are required to move conclusively test a possible connection between TEs and diversification rates.

\subsection{Are Transposable Elements and Hybrid Dysgenesis a Source of Selection for Reinforcement?}

Hybrid dysgenesis is a phenomenon that occurs in animals and might also exist in plants. Even though its natural frequency remains currently unknown, it is possible that it might be rather common [243,244]. Similarly, reinforcement, the evolutionary process in which prezygotic isolation is strengthened as a byproduct of the production of unfit hybrids, seems to be pervasive in nature [306]. If F1 interspecific hybrids consistently suffer fitness defects due to hybrid dysgenesis, then natural selection might indirectly penalize individuals that mate with heterospecifics, thus fostering the completion of speciation (i.e., increasing RI until there is cessation of gene flow). This question also remains unanswered and will require the identification of sister species that hybridize in nature and for which hybrid dysgenesis represents a major cost to heterospecific mating (Questions 10-11 in Box 1).

Box 1. Unanswered questions about the connection between TEs and speciation.

1. Are interspecific differences in flowering time disproportionately caused by TEs?

2. Do transposons play a significant role in pathogen adaptation to new hosts?

3. How commonly are TEs involved in antibiotic resistance?

4. How is the likelihood of chromosomal inversions caused by recombination affected by TEs?

5. What is the role of TEs in causing hybrid breakdown?

6. Do TEs regularly mediate the transition from outcrossing to self-crossing in fungi?

7. What is the taxonomical distribution of TEs?

8. Do TEs cause changes in the net rates of diversification across the tree of life?

9. Can TEs be deleterious enough to cause extinction?

10. Is introgression facilitated or hampered by TEs?

11. Does hybrid dysgenesis facilitate speciation by reinforcement?

12. Can TE-repressor systems generate hybrid incompatibilities during speciation?

\section{Conclusions}

Transposable elements are hypothesized to promote bursts of diversification or biological and genomic differentiation between species (e.g., [94,99]). Yet there is little direct evidence that TEs can indeed facilitate RI and ultimately speciation. That does not mean TEs are not related to the generation of new genetic elements, genetic circuits, and ultimately of phenotypes. On the contrary, TEs are commonly associated with the origin of new genetic and phenotypic diversity through gene regulatory element innovation, genic disruptions, siRNA/epigenetic suppressor mismatches, and chromosomal remodeling. In vertebrates, TEs have regularly contributed to the evolution of regulatory and coding sequences, leading to new lineage-specific gene regulations and functions. Their role has been pivotal to generate new phenotypic diversity. In primates for example, TEs are the main source of new variants in regulatory sequences [307]. In angiosperms a significant portion of adaptive novelty is due to the activity of TEs (active TE-Thrust), resulting in an extraordinary array of genetic changes, including gene modifications, duplications, altered expression patterns, and exaptation to create novel genes, with occasional gene disruption [118]. Even though it is clear that TEs are involved in generating the genetic material for new traits (some of them involved in adaptations), the question of whether TEs are involved in RI has remained largely understudied. The combination of natural history, genetics and genomics will reveal the prevalence of TEs in nature and to what extent they have played a role in generating and sustaining new organismal diversity. 
Acknowledgments: We would like to thank Christopher H. Martin, Colin S. Maxwell, Corbin Jones, Roberto Marquez, and the members of the Matute lab for helpful scientific discussions and comments. This work was supported in part by National Institutes of Health award R01GM121750 to DRM. The authors declare no conflicts of interest.

Conflicts of Interest: The authors declare no conflict of interest.

\section{References}

1. Coyne, J.A.; Orr, H.A. Speciation; Oxford University Press, Inc.: Sunderland, MA, USA, 2004.

2. Darwin, C. On the Origin of Species by Means of Natural Selection; Murray: London, UK, 1859.

3. Dobzhansky, T. Genetic nature of species differences. Am. Nat. 1937, 71, 404-420.

4. Coyne, J.A.; Orr, H.A. Patterns of speciation in Drosophila. Evolution (N. Y.) 1989, 43, 362-381.

5. Coyne, J.A.; Orr, H.A. "Patterns of speciation in Drosophila" Revisited. Evolution (N. Y.) 1997, 51, $295-303$.

6. Abbott, R.; Albach, D.; Ansell, S.; Arntzen, J.W.; Baird, S.J.; Bierne, N.; Boughman, J.; Brelsford, A.; Buerkle, C.A.; Buggs, R.; et al. Hybridization and speciation. J. Evol. Biol. 2013, 26, 229-246. [CrossRef] [PubMed]

7. Harrison, R.G. The language of speciation. Evolution 2012, 66, 3643-3657. [CrossRef] [PubMed]

8. Liou, L.W.; Price, T.D. Speciation by reinforcement of premating isolation. Evolution (N. Y.) 1994, 48, 1451-1459.

9. Rundle, H.D.; Nosil, P. Ecological speciation. Ecol. Lett. 2005, 8, 336-352. [CrossRef]

10. Seehausen, O.; Butlin, R.K.; Keller, I.; Wagner, C.E.; Boughman, J.W.; Hohenlohe, P.A.; Peichel, C.L.; Saetre, G.P.; Bank, C.; Brännström, A.; et al. Genomics and the origin of species. Nat. Rev. Genet. 2014, 15, 176-192. [CrossRef] [PubMed]

11. Maan, M.E.; Seehausen, O. Ecology, sexual selection and speciation. Ecol. Lett. 2011, 14, 591-602. [CrossRef] [PubMed]

12. Bolnick, D.I.; Near, T.J. Tempo of hybrid inviability in centrarchid fishes (Teleostei: Centrarchidae). Evolution 2005, 59, 1754-1767. [CrossRef] [PubMed]

13. Moyle, L.C.; Nakazato, T. Hybrid Incompatibility snowballs between Solanum species. Science 2010, 329, 1521-1523. [CrossRef] [PubMed]

14. Matute, D.R.; Butler, I.A.; Turissini, D.A.; Coyne, J.A. A Test of the snowball theory for the rate of evolution of hybrid incompatibilities. Science 2010, 329, 1518-1521. [CrossRef] [PubMed]

15. Wang, R.J.; White, M.A.; Payseur, B.A. The pace of hybrid incompatibility evolution in house mice. Genetics 2015, 201, 229-242. [CrossRef] [PubMed]

16. Orr, H.A. The genetic basis of reproductive isolation: Insights from Drosophila. Proc. Natl. Acad. Sci. USA 2005, 102 (Suppl. 1), 6522-6526. [CrossRef] [PubMed]

17. Widmer, A.; Lexer, C.; Cozzolino, S. Evolution of reproductive isolation in plants. Heredity (Edinb.) 2009, 102, 31-38. [CrossRef] [PubMed]

18. Noor, M.A.F.; Grams, K.L.; Bertucci, L.A.; Reiland, J. Chromosomal inversions and the reproductive isolation of species. Proc. Natl. Acad. Sci. USA 2001, 98, 12084-12088. [CrossRef] [PubMed]

19. Kirkpatrick, M.; Barton, N. Chromosome inversions, local adaptation and speciation. Genetics 2006, 173, 419-434. [CrossRef] [PubMed]

20. Hoffmann, A.A.; Rieseberg, L.H. Revisiting the impact of inversions in evolution: From population genetic markers to drivers of adaptive shifts and speciation? Annu. Rev. Ecol. Evol. Syst. 2008, 39, 21-42. [CrossRef] [PubMed]

21. Wicker, T.; Sabot, F.; Hua-Van, A.; Bennetzen, J.L.; Capy, P.; Chalhoub, B.; Flavell, A.; Leroy, P.; Morgante, M.; Panaud, O.; et al. A unified classification system for eukaryotic transposable elements. Nat. Rev. Genet. 2007, 8, 973-982. [CrossRef] [PubMed]

22. Gregory, T.R.; Nicol, J.A.; Tamm, H.; Kullman, B.; Kullman, K.; Leitch, I.J.; Murray, B.G.; Kapraun, D.F.; Greilhuber, J.; Bennett, M.D. Eukaryotic genome size databases. Nucleic Acids Res. 2007, 35 (Suppl. 1), D332-D338. [CrossRef] [PubMed]

23. Bennetzen, J.L.; Wang, H. The contributions of transposable elements to the structure, function, and evolution of plant genomes. Annu. Rev. Plant Biol. 2014, 65, 505-530. [CrossRef] [PubMed]

24. Charlesworth, B.; Langley, C.H.; Sniegowski, P.D. Transposable element distributions in Drosophila. Genetics 1997, 147, 1993-1995. [PubMed]

25. Kidwell, M.G. Transposable elements and the evolution of genome size in eukaryotes. Genetica 2002, 115, $49-63$. [CrossRef] [PubMed] 
26. Kidwell, M.G.; Lisch, D. Transposable elements as sources of variation in animals and plants. Proc. Natl. Acad. Sci. USA 1997, 94, 7704-7711. [CrossRef] [PubMed]

27. Bennett, E.A.; Coleman, L.E.; Tsui, C.; Pittard, W.S.; Devine, S.E. Natural genetic variation caused by transposable elements in humans. Genetics 2004, 168, 933-951. [CrossRef] [PubMed]

28. Lockton, S.; Gaut, B.S. The evolution of transposable elements in natural populations of self-fertilizing Arabidopsis thaliana and its outcrossing relative Arabidopsis lyrata. BMC Evol. Biol. 2010, 10, 10. [CrossRef] [PubMed]

29. McClintock, B. The origin and behavior of mutable loci in maize. Proc. Natl. Acad. Sci. USA 1950, 36, 344-355. [CrossRef] [PubMed]

30. Oliver, K.R.; Greene, W.K. Transposable elements: Powerful facilitators of evolution. BioEssays 2009, 31, 703-714. [CrossRef] [PubMed]

31. Okamoto, H.; Hirochika, H. Silencing of transposable elements in plants. Trends Plant Sci. 2001, 6, 527-534. [CrossRef]

32. Feschotte, C.; Jiang, N.; Wessler, S.R. Plant transposable elements: Where genetics meets genomics. Nat. Rev. Genet. 2002, 3, 329-341. [CrossRef] [PubMed]

33. Woodhouse, M.R.; Freeling, M.; Lisch, D. Initiation, establishment, and maintenance of heritable $M u D R$ transposon silencing in maize are mediated by distinct factors. PLoS Biol. 2006, 4, 1678-1688. [CrossRef] [PubMed]

34. Feschotte, C. Transposable elements and the evolution of regulatory networks. Nat. Rev. Genet. 2008, 9, $397-405$. [CrossRef] [PubMed]

35. Voytas, D.F.; Cummings, M.P.; Koniczny, A.; Ausubel, F.M.; Rodermel, S.R. copia-like retrotransposons are ubiquitous among plants. Proc. Natl. Acad. Sci. USA 1992, 89, 7124-7128. [CrossRef] [PubMed]

36. Flavell, A.J.; Dunbar, E.; Anderson, R.; Pearce, S.R.; Hartley, R.; Kumar, A. Ty1-copia group retrotransposons are ubiquitous and heterogeneous in higher plants. Nucleic Acids Res. 1992, 20, 3639-3644. [CrossRef] [PubMed]

37. Aziz, R.K.; Breitbart, M.; Edwards, R.A. Transposases are the most abundant, most ubiquitous genes in nature. Nucleic Acids Res. 2010, 38, 4207-4217. [CrossRef] [PubMed]

38. Van De Lagemaat, L.N.; Landry, J.R.; Mager, D.L.; Medstrand, P. Transposable elements in mammals promote regulatory variation and diversification of genes with specialized functions. Trends Genet. 2003, 19, 530-536. [CrossRef] [PubMed]

39. Kapusta, A.; Kronenberg, Z.; Lynch, V.J.; Zhuo, X.; Ramsay, L.; Bourque, G.; Yandell, M.; Feschotte, C. Transposable elements are major contributors to the origin, diversification, and regulation of vertebrate long noncoding RNAs. PLoS Genet. 2013, 9, e1003470. [CrossRef] [PubMed]

40. Flutre, T.; Duprat, E.; Feuillet, C.; Quesneville, H. Considering transposable element diversification in de novo annotation approaches. PLoS ONE 2011, 6, 0016526. [CrossRef] [PubMed]

41. Hollister, J.D.; Gaut, B.S. Epigenetic silencing of transposable elements: A trade-off between reduced transposition and deleterious effects on neighboring gene expression. Genome Res. 2009, 19, 1419-1428. [CrossRef] [PubMed]

42. Arkhipova, I.; Meselson, M. Deleterious transposable elements and the extinction of asexuals. BioEssays 2005, 27, 76-85. [CrossRef] [PubMed]

43. Vinogradov, A.E. Evolution of genome size: Multilevel selection, mutation bias or dynamical chaos? Curr. Opin. Genet. Dev. 2004, 14, 620-626. [CrossRef] [PubMed]

44. Brunet, T.D.; Doolittle, W.F. Multilevel selection theory and the evolutionary functions of transposable elements. Genome Biol. Evol. 2015, 7, 2445-2457. [CrossRef] [PubMed]

45. Fablet, M.; Vieira, C. Evolvability, epigenetics and transposable elements. Biomol. Concepts 2011, 2, $333-341$. [CrossRef] [PubMed]

46. Copeland, C.S.; Mann, V.H.; Morales, M.E.; Kalinna, B.H.; Brindley, P.J. The Sinbad retrotransposon from the genome of the human blood fluke, Schistosoma mansoni, and the distribution of related Pao-like elements. BMC Evol. Biol. 2005, 5. [CrossRef] [PubMed]

47. De La Chaux, N.; Wagner, A. BEL/Pao retrotransposons in metazoan genomes. BMC Evol. Biol. 2011, 11. [CrossRef] [PubMed]

48. Piednoël, M.; Gonçalves, I.R.; Higuet, D.; Bonnivard, E. Eukaryote DIRS1-like retrotransposons: An overview. BMC Genom. 2011, 12, 621. [CrossRef] [PubMed] 
49. Cappello, J.; Cohen, S.M.; Lodish, H.F. Dictyostelium transposable element DIRS-1 preferentially inserts into, DIRS-1 sequences. Mol. Cell. Biol. 1984, 4, 2207-2213. [CrossRef] [PubMed]

50. Sandmeyer, S.B. Yeast retrotransposons. Curr. Opin. Genet. Dev. 1992, 2, 705-711. [CrossRef]

51. Devine, S.E.; Boeke, J.D. Integration of the yeast retrotransposon Ty1 is targeted to regions upstream of genes transcribed by RNA polymerase III. Genes Dev. 1996, 10, 620-633. [CrossRef] [PubMed]

52. Dai, J.; Xie, W.; Brady, T.L.; Gao, J.; Voytas, D.F. Phosphorylation regulates integration of the yeast ty5 retrotransposon into heterochromatin. Mol. Cell 2007, 27, 289-299. [CrossRef] [PubMed]

53. Nekrutenko, A.; Li, W.H. Transposable elements are found in a large number of human protein-coding genes. Trends Genet. 2001, 17, 619-621. [CrossRef]

54. Chaboissier, M.C.; Bucheton, A.; Finnegan, D.J. Copy number control of a transposable element, the I factor, a LINE-like element in Drosophila. Proc. Natl. Acad. Sci. USA 1998, 95, 11781-11785. [CrossRef] [PubMed]

55. Evgen'ev, M.B.; Zelentsova, H.; Shostak, N.; Kozitsina, M.; Barskyi, V.; Lankenau, D.H.; Corces, V.G. Penelope, a new family of transposable elements and its possible role in hybrid dysgenesis in Drosophila virilis. Proc. Natl. Acad. Sci. USA 1997, 94, 196-201. [CrossRef] [PubMed]

56. Koyama, T.; Kondo, H.; Aoki, T.; Hirono, I. Identification of two Penelope-like elements with different structures and chromosome localization in kuruma shrimp genome. Mar. Biotechnol. 2013, 15, 115-123. [CrossRef] [PubMed]

57. Youngman, S.; Van Luenen, H.G.; Plasterk, R.H. Rte-1, a retrotransposon-like element in Caenorhabditis elegans. FEBS Lett. 1996, 380, 1-7. [CrossRef]

58. Tay, W.T.; Behere, G.T.; Batterham, P.; Heckel, D.G. Generation of microsatellite repeat families by RTE retrotransposons in lepidopteran genomes. BMC Evol Biol 2010, 10. [CrossRef] [PubMed]

59. Župunski, V.; Gubenšek, F.; Kordiš, D. Evolutionary dynamics and evolutionary history in the RTE clade of non-LTR retrotransposons. Mol. Biol. Evol. 2001, 18, 1849-1863. [CrossRef] [PubMed]

60. Ponicsan, S.L.; Kugel, J.F.; Goodrich, J.A. Genomic gems: SINE RNAs regulate mRNA production. Curr. Opin. Genet. Dev. 2010, 20, 149-155. [CrossRef] [PubMed]

61. Majewski, J.; Ott, J. Distribution and characterization of regulatory elements in the human genome. Genome Res. 2002, 12, 1827-1836. [CrossRef] [PubMed]

62. Hartl, D.L. Discovery of the transposable element mariner. Genetics 2001, 157, 471-476. [PubMed]

63. Kato, M.; Takashima, K.; Kakutani, T. Epigenetic control of CACTA transposon mobility in Arabidopsis thaliana. Genetics 2004, 168, 961-969. [CrossRef] [PubMed]

64. Kojima, K.K.; Jurka, J. Crypton transposons: Identification of new diverse families and ancient domestication events. Mob. DNA 2011, 2, 12. [CrossRef] [PubMed]

65. Lai, J.; Li, Y.; Messing, J.; Dooner, H.K. Gene movement by Helitron transposons contributes to the haplotype variability of maize. Proc. Natl. Acad. Sci. USA 2005, 102, 9068-9073. [CrossRef] [PubMed]

66. Ladevèze, V.; Aulard, S.; Chaminade, N.; Périquet, G.; Lemeunier, F. Hobo transposons causing chromosomal breakpoints. Proc. Biol. Sci. 1998, 265, 1157-1159. [CrossRef] [PubMed]

67. Lim, J.K. Intrachromosomal rearrangements mediated by hobo transposons in Drosophila melanogaster. Proc. Natl. Acad. Sci. USA 1988, 85, 9153-9157. [CrossRef] [PubMed]

68. Streck, R.D.; Macgaffey, J.E.; Beckendorf, S.K. The structure of hobo transposable elements and their insertion sites. Embo J. 1986, 5, 3615-3623. [PubMed]

69. Srivastav, S.P.; Kelleher, E.S. Paternal induction of hybrid dysgenesis in Drosophila melanogaster is weakly correlated with both p-element and hobo element dosage. G3 Genes Genomes Genet. 2017, 7, 1487-1497. [CrossRef] [PubMed]

70. Malinsky, S.; Bucheton, A.; Busseau, I. New insights on homology-dependent silencing of I factor activity by transgenes containing ORF1 in Drosophila melanogaster. Genetics 2000, 156, 1147-1155. [PubMed]

71. Jensen, S.; Gassama, M.P.; Dramard, X.; Heidmann, T. Regulation of I-transposon activity in Drosophila: Evidence for cosuppression of nonhomologous transgenes and possible role of ancestral I-related pericentromeric elements. Genetics 2002, 162, 1197-1209. [PubMed]

72. Brunet, F.; Godin, F.; David, J.R.; Capy, P. The mariner transposable element in the drosophilidae family. Heredity (Edinb.) 1994, 73, 377-385. [CrossRef] [PubMed]

73. Robertson, H.M. The mariner transposable element is widespread in insects. Nature 1993, 362, $241-245$. [CrossRef] [PubMed] 
74. Hartl, D.L.; Lohe, A.R.; Lozovskaya, E.R. Regulation of the transposable element mariner. Genetica 1997, 100, $177-184$. [CrossRef] [PubMed]

75. Nakayashiki, H. The Trickster in the genome: Contribution and control of transposable elements. Genes Cells 2011, 16, 827-841. [CrossRef] [PubMed]

76. Pritham, E.J.; Putliwala, T.; Feschotte, C. Mavericks, a novel class of giant transposable elements widespread in eukaryotes and related to DNA viruses. Gene 2007, 390, 3-17. [CrossRef] [PubMed]

77. Liu, S.; Yeh, C.T.; Ji, T.; Ying, K.; Wu, H.; Tang, H.M.; Fu, Y.; Nettleton, D.; Schnable, P.S. Mu transposon insertion sites and meiotic recombination events co-localize with epigenetic marks for open chromatin across the maize genome. PLoS Genet. 2009, 5, e1000733. [CrossRef] [PubMed]

78. Kidwell, M.G.; Kidwell, J.F.; Sved, J.A. Hybrid dysgenesis in Drosophila melanogaster: A syndrome of aberrant traits including mutation, sterility and male recombination. Genetics 1977, 86, 813-833. [PubMed]

79. Clark, J.B.; Altheide, T.K.; Schlosser, M.J.; Kidwell, M.G. Molecular evolution of P transposable elements in the genus Drosophila. I. The saltans and willistoni species groups. Mol. Biol. Evol. 1995, 12, 902-913. [PubMed]

80. Haring, E.; Hagemann, S.; Pinsker, W. Different evolutionary behaviour of P element subfamilies: M-type and O-type elements in Drosophila bifasciata and D. imaii. Gene 1995, 163, 197-202. [CrossRef]

81. Nouroz, F.; Noreen, S.; Heslop-Harrison, J.S. Characterization and diversity of novel PIF/Harbinger DNA transposons in Brassica genomes. Pak. J. Bot. 2016, 48, 167-178.

82. Liang, Q.; Kong, J.; Stalker, J.; Bradley, A. Chromosomal mobilization and reintegration of Sleeping Beauty and PiggyBac transposons. Genesis 2009, 47, 404-408. [CrossRef] [PubMed]

83. Nishizawa-Yokoi, A.; Endo, M.; Osakabe, K.; Saika, H.; Toki, S. Precise marker excision system using an animal-derived piggyBac transposon in plants. Plant J. 2014, 77, 454-463. [CrossRef] [PubMed]

84. Kaminker, J.S.; Bergman, C.M.; Kronmiller, B.; Carlson, J.; Svirskas, R.; Patel, S.; Frise, E.; Wheeler, D.A.; Lewis, S.E.; Rubin, G.M.; et al. The transposable elements of the Drosophila melanogaster euchromatin: A genomics perspective. Genome Biol. 2002, 3, 1-20. [CrossRef]

85. Tudor, M.; Lobocka, M.; Goodell, M.; Pettitt, J.; O'Hare, K. The pogo transposable element family of Drosophila melanogaster. MGG Mol. Gen. Genet. 1992, 232, 126-134. [CrossRef] [PubMed]

86. Hencken, C.G.; Li, X.; Craig, N.L. Functional characterization of an active Rag-like transposase. Nat. Struct. Mol. Biol. 2012, 19, 834-836. [CrossRef] [PubMed]

87. Muotri, A.R.; Marchetto, M.C.N.; Coufal, N.G.; Gage, F.H. The necessary junk: New functions for transposable elements. Hum. Mol. Genet. 2007, 16, R159-R167. [CrossRef] [PubMed]

88. Kapitonov, V.V.; Jurka, J. RAG1 core and V(D)J recombination signal sequences were derived from Transib transposons. PLoS Biol. 2005, 3, 0998-1011. [CrossRef] [PubMed]

89. Volff, J.N. Turning junk into gold: Domestication of transposable elements and the creation of new genes in eukaryotes. BioEssays 2006, 28, 913-922. [CrossRef] [PubMed]

90. Hurst, G.D.D.; Schilthuizen, M. Selfish genetic elements and speciation. Heredity (Edinb.) 1998, 80, 2-8. [CrossRef]

91. Werren, J.H. Selfish genetic elements, genetic conflict, and evolutionary innovation. Proc. Natl. Acad. Sci. USA 2011, 108 (Suppl. 2), 10863-10870. [CrossRef] [PubMed]

92. Crespi, B.; Nosil, P. Conflictual speciation: Species formation via genomic conflict. Trends Ecol. Evol. 2013, 28 , 48-57. [CrossRef] [PubMed]

93. Ginzburg, L.R.; Bingham, P.M.; Yoo, S. On the theory of speciation induced by transposable elements. Genetics 1984, 107, 331-341. [PubMed]

94. Zeh, D.W.; Zeh, J.A.; Ishida, Y. Transposable elements and an epigenetic basis for punctuated equilibria. BioEssays 2009, 31, 715-726. [CrossRef] [PubMed]

95. Orr, H.A.; Presgraves, D.C. Speciation by postzygotic isolation: Forces, genes and molecules. BioEssays 2000, 22, 1085-1094. [CrossRef]

96. Stapley, J.; Santure, A.W.; Dennis, S.R. Transposable elements as agents of rapid adaptation may explain the genetic paradox of invasive species. Mol. Ecol. 2015, 24, 2241-2252. [CrossRef] [PubMed]

97. Casacuberta, E.; González, J. The impact of transposable elements in environmental adaptation. Mol. Ecol. 2013, 22, 1503-1517. [CrossRef] [PubMed]

98. Lisch, D. How important are transposons for plant evolution? Nat. Rev. Genet. 2013, 14, 49-61. [CrossRef] [PubMed]

99. Belyayev, A. Bursts of transposable elements as an evolutionary driving force. J. Evol. Biol. 2014, 27, $2573-2584$. [CrossRef] [PubMed] 
100. Comai, L.; Madlung, A.; Josefsson, C.; Tyagi, A. Do the different parental "heteromes" cause genomic shock in newly formed allopolyploids? Philos. Trans. R. Soc. B Biol. Sci. 2003, 358, 1149-1155. [CrossRef] [PubMed]

101. Tapia, G.; Verdugo, I.; Yañez, M.; Ahumada, I.; Theoduloz, C.; Cordero, C.; Poblete, F.; González, E.; Ruiz-Lara, S. Involvement of ethylene in stress-induced expression of the, TLC1.1 retrotransposon from Lycopersicon chilense Dun. Plant Physiol. 2005, 138, 2075-2086. [CrossRef] [PubMed]

102. Servedio, M.R.; Van Doorn, G.S.; Kopp, M.; Frame, A.M.; Nosil, P. Magic traits in speciation: "magic" but not rare? Trends Ecol. Evol. 2011, 26, 389-397. [CrossRef] [PubMed]

103. Thibert-Plante, X.; Gavrilets, S. Evolution of mate choice and the so-called magic traits in ecological speciation. Ecol. Lett. 2013, 16, 1004-1013. [CrossRef] [PubMed]

104. Nosil, P.; Vines, T.H.; Funk, D.J. Reproductive isolation caused by natural selection against immigrants from divergent habitats. Evolution 2005, 59, 705-719. [CrossRef] [PubMed]

105. Hendry, A.P.; Day, T. Population structure attributable to reproductive time: Isolation by time and adaptation by time. Mol. Ecol. 2005, 14, 901-916. [CrossRef] [PubMed]

106. Ehrlén, J. Selection on flowering time in a life-cycle context. Oikos 2015, 124, 92-101. [CrossRef]

107. Tamaki, S.; Tsuji, H.; Matsumoto, A.; Fujita, A.; Shimatani, Z.; Terada, R.; Sakamoto, T.; Kurata, T.; Shimamoto, K. FT-like proteins induce transposon silencing in the shoot apex during floral induction in rice. Proc. Natl. Acad. Sci. USA 2015, 112, E901-E910. [CrossRef] [PubMed]

108. Tooley, P.W.; Garfinkel, D.J. Presence of Ty1-copia group retrotransposon sequences in the potato late blight pathogen Phytophthora infestans. Mol. Plant Microbe Interact. 1996, 9, 305-309. [CrossRef] [PubMed]

109. Whisson, S.C.; Vetukuri, R.R.; Avrova, A.O.; Dixelius, C. Can silencing of transposons contribute to variation in effector gene expression in Phytophthora infestans? Mob. Genet. Elem. 2012, 2, 110-114. [CrossRef] [PubMed]

110. Lengeler, K.B.; Fox, D.S.; Fraser, J.A.; Allen, A.; Forrester, K.; Dietrich, F.S.; Heitman, J. Mating-type locus of Cryptococcus neoformans: A step in the evolution of sex chromosomes. Eukaryot. Cell 2002, 1, 704-718. [CrossRef] [PubMed]

111. Corcoran, P.; Anderson, J.L.; Jacobson, D.J.; Sun, Y.; Ni, P.; Lascoux, M.; Johannesson, H. Introgression maintains the genetic integrity of the mating-type determining chromosome of the fungus Neurospora tetrasperma. Genome Res. 2016, 26, 486-498. [CrossRef] [PubMed]

112. Laurie, J.D.; Ali, S.; Linning, R.; Mannhaupt, G.; Wong, P.; Güldener, U.; Münsterkötter, M.; Moore, R.; Kahmann, R.; Bakkeren, G.; et al. Genome comparison of barley and maize smut fungi reveals targeted loss of RNA silencing components and species-specific presence of transposable elements. Plant Cell 2012, 24, 1733-1745. [CrossRef] [PubMed]

113. Ding, Y.; Berrocal, A.; Morita, T.; Longden, K.D.; Stern, D.L. Natural courtship song variation caused by an intronic retroelement in an ion channel gene. Nature 2016, 536, 329-332. [CrossRef] [PubMed]

114. Cáceres, M.; Ranz, J.M.; Barbadilla, A.; Long, M.; Ruiz, A. Generation of a widespread Drosophila inversion by a transposable element. Science 1999, 285, 415-418. [PubMed]

115. Gómez, G.A.; Hasson, E. Transpecific polymorphisms in an inversion linked esterase locus in Drosophila buzzatii. Mol. Biol. Evol. 2003, 20, 410-423. [CrossRef] [PubMed]

116. Bregliano, J.C.; Picard, G.; Bucheton, A.; Pelisson, A.; Lavige, J.M.; L'Héritier, P. Hybrid dysgenesis in Drosophila melanogaster. Science 1980, 207, 606-611. [CrossRef] [PubMed]

117. Hill, T.; Schlötterer, C.; Betancourt, A.J. Hybrid dysgenesis in Drosophila simulans associated with a rapid invasion of the P-Element. PLoS Genet. 2016, 12, e1005920.

118. Oliver, K.R.; McComb, J.A.; Greene, W.K. Transposable elements: Powerful contributors to angiosperm evolution and diversity. Genome Biol. Evol. 2013, 5, 1886-1901. [CrossRef] [PubMed]

119. Kinoshita, T. Reproductive barrier and genomic imprinting in the endosperm of flowering plants. Genes Genet. Syst. 2007, 82, 177-186. [CrossRef] [PubMed]

120. Waters, A.J.; Makarevitch, I.; Eichten, S.R.; Swanson-Wagner, R.A.; Yeh, C.T.; Xu, W.; Schnable, P.S.; Vaughn, M.W.; Gehring, M.; Springer, N.M. Parent-of-origin effects on gene expression and DNA methylation in the maize endosperm. Plant Cell 2011, 23, 4221-4233. [CrossRef] [PubMed]

121. Gardner, E.J.; Lam, V.K.; Harris, D.N.; Chuang, N.T.; Scott, E.C.; Pittard, W.S.; Mills, R.E.; Devine, S.E.; 1000 Genomes Project Consortium. The Mobile Element Locator Tool (MELT): Population-scale mobile element discovery and biology. Genome Res. 2017, 27, 1916-1929. [CrossRef] [PubMed]

122. Zhuang, J.; Wang, J.; Theurkauf, W.; Weng, Z. TEMP: A computational method for analyzing transposable element polymorphism in populations. Nucleic Acids Res. 2014, 42, 6826-6838. [CrossRef] [PubMed] 
123. Hénaff, E.; Zapata, L.; Casacuberta, J.M.; Ossowski, S. Jitterbug: Somatic and germline transposon insertion detection at single-nucleotide resolution. BMC Genom. 2015, 16. [CrossRef] [PubMed]

124. Kroon, M.; Lameijer, E.W.; Lakenberg, N.; Hehir-Kwa, J.Y.; Thung, D.T.; Slagboom, P.E.; Kok, J.N.; Ye, K. Detecting dispersed duplications in high-throughput sequencing data using a database-free approach. Bioinformatics 2015, 32, 505-510. [CrossRef] [PubMed]

125. Rahman, R.; Chirn, G.W.; Kanodia, A.; Sytnikova, Y.A.; Brembs, B.; Bergman, C.M.; Lau, N.C. Unique transposon landscapes are pervasive across Drosophila melanogaster genomes. Nucleic Acids Res. 2015, 43, 10655-10672. [CrossRef] [PubMed]

126. Thung, D.T.; de Ligt, J.; Vissers, L.E.; Steehouwer, M.; Kroon, M.; de Vries, P.; Slagboom, E.P.; Ye, K.; Veltman, J.A.; Hehir-Kwa, J.Y. Mobster: Accurate detection of mobile element insertions in next generation sequencing data. Genome Biol. 2014, 15, 488. [CrossRef] [PubMed]

127. Wu, J.; Lee, W.P.; Ward, A.; Walker, J.A.; Konkel, M.K.; Batzer, M.A.; Marth, G.T. Tangram: A comprehensive toolbox for mobile element insertion detection. BMC Genom. 2014, 15. [CrossRef] [PubMed]

128. Zook, J.M.; Chapman, B.; Wang, J.; Mittelman, D.; Hofmann, O.; Hide, W.; Salit, M. Integrating human sequence data sets provides a resource of benchmark, SNP and indel genotype calls. Nat. Biotechnol. 2014, 32, 246-251. [CrossRef] [PubMed]

129. Nakagome, M.; Solovieva, E.; Takahashi, A.; Yasue, H.; Hirochika, H.; Miyao, A. Transposon Insertion Finder (TIF): A novel program for detection of de novo transpositions of transposable elements. BMC Bioinf. 2014, 15. [CrossRef] [PubMed]

130. Helman, E.; Lawrence, M.S.; Stewart, C.; Sougnez, C.; Getz, G.; Meyerson, M. Somatic retrotransposition in human cancer revealed by whole-genome and exome sequencing. Genome Res. 2014, 24, 1053-1063. [CrossRef] [PubMed]

131. Tubio, J.M.; Li, Y.; Ju, Y.S.; Martincorena, I.; Cooke, S.L.; Tojo, M.; Gundem, G.; Pipinikas, C.P.; Zamora, J.; Raine, K.; et al. Extensive transduction of nonrepetitive, DNA mediated by L1 retrotransposition in cancer genomes. Science 2014, 345. [CrossRef] [PubMed]

132. Chen, K.; Chen, L.; Fan, X.; Wallis, J.; Ding, L.; Weinstock, G. TIGRA: A targeted iterative graph routing assembler for breakpoint assembly. Genome Res. 2014, 24, 310-317. [CrossRef] [PubMed]

133. Gilly, A.; Etcheverry, M.; Madoui, M.A.; Guy, J.; Quadrana, L.; Alberti, A.; Martin, A.; Heitkam, T.; Engelen, S.; Labadie, K.; et al. TE-Tracker: Systematic identification of transposition events through whole-genome resequencing. BMC Bioinf. 2014, 15. [CrossRef] [PubMed]

134. Ewing, A.D.; Ballinger, T.J.; Earl, D.; Harris, C.C.; Ding, L.; Wilson, R.K.; Haussler, D. Retrotransposition of gene transcripts leads to structural variation in mammalian genomes. Genome Biol. 2013, 14, 1-14. [CrossRef] [PubMed]

135. Robb, S.M.; Lu, L.; Valencia, E.; Burnette, J.M.; Okumoto, Y.; Wessler, S.R.; Stajich, J.E. The use of RelocaTE and unassembled short reads to produce high-resolution snapshots of transposable element generated diversity in rice. G3 Genes Genomes Genet. 2013, 3, 949-957. [CrossRef] [PubMed]

136. Lee, E.; Iskow, R.; Yang, L.; Gokcumen, O.; Haseley, P.; Luquette, L.J.; Lohr, J.G.; Harris, C.C.; Ding, L.; Wilson, R.K.; et al. Landscape of somatic retrotransposition in human cancers. Science 2012, 337, 967-971. [CrossRef] [PubMed]

137. Linheiro, R.S.; Bergman, C.M. Whole genome resequencing reveals natural target site preferences of transposable elements in Drosophila melanogaster. PLoS ONE 2012, 7, e0030008. [CrossRef] [PubMed]

138. Platzer, A.; Nizhynska, V.; Long, Q. TE-Locate: A tool to locate and group transposable element occurrences using paired-end next-generation sequencing data. Biology (Basel) 2012, 1, 395-410. [CrossRef] [PubMed]

139. Hormozdiari, F.; Hajirasouliha, I.; Dao, P.; Hach, F.; Yorukoglu, D.; Alkan, C.; Eichler, E.E.; Sahinalp, S.C. Next-generation VariationHunter: Combinatorial algorithms for transposon insertion discovery. Bioinformatics 2010, 26, i350-i357. [CrossRef] [PubMed]

140. Quinlan, A.R.; Clark, R.A.; Sokolova, S.; Leibowitz, M.L.; Zhang, Y.; Hurles, M.E.; Mell, J.C.; Hall, I.M. Genome-wide mapping and assembly of structural variant breakpoints in the mouse genome. Genome Res. 2010, 20, 623-635. [CrossRef] [PubMed]

141. Lee, H.; Lee, M.; Mohammed Ismail, W.; Rho, M.; Fox, G.C.; Oh, S.; Tang, H. MGEScan: A Galaxy based system for identifying retrotransposons in genomes. Bioinformatics 2016, 32, 2502-2504. [CrossRef] [PubMed]

142. Novák, P.; Neumann, P.; Macas, J. Graph-based clustering and characterization of repetitive sequences in next-generation sequencing data. BMC Bioinf. 2010, 11, 378. [CrossRef] [PubMed] 
143. Singh, V.; Mishra, R.K. RISCI-Repeat Induced Sequence Changes Identifier: A comprehensive, comparative genomics-based, in silico subtractive hybridization pipeline to identify repeat induced sequence changes in closely related genomes. BMC Bioinf. 2010, 11, 609. [CrossRef] [PubMed]

144. Pestilli, F.; Yeatman, J.D.; Rokem, A.; Kay, K.N.; Wandell, B.A. Evaluation and statistical inference for human connectomes. Nat. Methods 2014, 11, 1058-1063. [CrossRef] [PubMed]

145. Ellinghaus, D.; Kurtz, S.; Willhoeft, U. LTRharvest, an efficient and flexible software for de novo detection of LTR retrotransposons. BMC Bioinf. 2008, 9. [CrossRef] [PubMed]

146. Du, C.; Caronna, J.; He, L.; Dooner, H.K. Computational prediction and molecular confirmation of Helitron transposons in the maize genome. BMC Genom. 2008, 9, 51. [CrossRef] [PubMed]

147. Lorenzi, H.; Thiagarajan, M.; Haas, B.; Wortman, J.; Hall, N.; Caler, E. Genome wide survey, discovery and evolution of repetitive elements in three Entamoeba species. BMC Genom. 2008, 9, 595. [CrossRef] [PubMed]

148. Castelletti, S.; Tuberosa, R.; Pindo, M.; Salvi, S. A MITE transposon insertion is associated with differential methylation at the maize flowering time, QTL Vgt1. G3 Genes Genomes Genet. 2014, 4, 805-812. [CrossRef] [PubMed]

149. Yang, Q.; Li, Z.; Li, W.; Ku, L.; Wang, C.; Ye, J.; Li, K.; Yang, N.; Li, Y.; Zhong, T.; et al. CACTA-like transposable element in $\mathrm{ZmCCT}$ attenuated photoperiod sensitivity and accelerated the postdomestication spread of maize. Proc. Natl. Acad. Sci. USA 2013, 110, 16969-16974. [CrossRef] [PubMed]

150. Liu, J.; He, Y.; Amasino, R.; Chen, X. siRNAs targeting an intronic transposon in the regulation of natural flowering behavior in Arabidopsis. Genes Dev. 2004, 18, 2873-2878. [CrossRef] [PubMed]

151. González, J.; Karasov, T.L.; Messer, P.W.; Petrov, D.A. Genome-wide patterns of adaptation to temperate environments associated with transposable elements in Drosophila. PLoS Genet. 2010, 6, e1000905. [CrossRef] [PubMed]

152. Kamoun, S. A Catalogue of the effector secretome of plant pathogenic Oomycetes. Annu. Rev. Phytopathol. 2006, 44, 41-60. [CrossRef] [PubMed]

153. Schulze-Lefert, P.; Panstruga, R. A molecular evolutionary concept connecting nonhost resistance, pathogen host range, and pathogen speciation. Trends Plant Sci. 2011, 16, 117-125. [CrossRef] [PubMed]

154. Restrepo, S.; Tabima, J.F.; Mideros, M.F.; Grünwald, N.J.; Matute, D.R. Speciation in fungal and oomycete plant pathogens. Annu. Rev. Phytopathol. 2014, 52, 289-316. [CrossRef] [PubMed]

155. Judelson, H.S. Genomics of the plant pathogenic oomycete Phytophthora: Insights into biology and evolution. Adv. Genet. 2007, 57, 97-141. [PubMed]

156. Kamoun, S.; Hraber, P.; Sobral, B.; Nuss, D.; Govers, F. Initial assessment of gene diversity for the oomycete pathogen Phytophthora infestans based on expressed sequences. Fungal Genet. Biol. 1999, 28, 94-106. [CrossRef] [PubMed]

157. Kamoun, S. Molecular genetics of pathogenic Oomycetes. Eukaryot. Cell 2003, 2, 191-199. [CrossRef] [PubMed]

158. Judelson, H.S. Sequence variation and genomic amplification of a family of Gypsy-like elements in the oomycete genus Phytophthora. Mol. Biol. Evol. 2002, 19, 1313-1322. [CrossRef] [PubMed]

159. Nielsen, K.; Heitman, J. Sex and virulence of human pathogenic Fungi. Adv. Genet. 2007, 57, 143-173. [PubMed]

160. Wilson, A.M.; Wilken, P.M.; Van Der Nest, M.A.; Steenkamp, E.T.; Wingfield, M.J.; Wingfield, B.D. Homothallism: An umbrella term for describing diverse sexual behaviours. IMA Fungus 2015, 6, 207-214. [CrossRef] [PubMed]

161. Korf, R.P. The terms homothallism and heterothallism. Nature 1952, 170, 534-535. [CrossRef] [PubMed]

162. Wendt, T.; Canela, M.B.F.; Klein, D.E.; Rios, R.I. Selfing facilitates reproductive isolation among three sympatric species of Pitcairnia (Bromeliaceae). Plant Syst. Evol. 2002, 232, 201-212. [CrossRef]

163. Baker, H.G. Reproductive methods as factors in speciation in flowering plants. Cold Spring Harb. Symp. Quant. Biol. 1959, 24, 177-191. [CrossRef] [PubMed]

164. Foxe, J.P.; Slotte, T.; Stahl, E.A.; Neuffer, B.; Hurka, H.; Wright, S.I. Recent speciation associated with the evolution of selfing in Capsella. Proc. Natl. Acad. Sci. USA 2009, 106, 5241-5245. [CrossRef] [PubMed]

165. Gioti, A.; Mushegian, A.A.; Strandberg, R.; Stajich, J.E.; Johannesson, H. Unidirectional evolutionary transitions in fungal mating systems and the role of transposable elements. Mol. Biol. Evol. 2012, 29, 3215-3226. [CrossRef] [PubMed]

166. Nygren, K.; Strandberg, R.; Wallberg, A.; Nabholz, B.; Gustafsson, T.; García, D.; Cano, J.; Guarro, J.; Johannesson, H. A comprehensive phylogeny of Neurospora reveals a link between reproductive mode and molecular evolution in fungi. Mol. Phylogenet. Evol. 2011, 59, 649-663. [CrossRef] [PubMed] 
167. Li, W.; Sullivan, T.D.; Walton, E.; Averette, A.F.; Sakthikumar, S.; Cuomo, C.A.; Klein, B.S.; Heitman, J. Identification of the mating-type (MAT) locus that controls sexual reproduction of Blastomyces dermatitidis. Eukaryot. Cell 2013, 12, 109-117. [CrossRef] [PubMed]

168. Rydholm, C.; Dyer, P.S.; Lutzoni, F. DNA sequence characterization and molecular evolution of, MAT1 and, MAT2 mating-type loci of the self-compatible ascomycete mold Neosartorya fischeri. Eukaryot. Cell 2007, 6, 868-874. [CrossRef] [PubMed]

169. Desjardins, C.A.; Champion, M.D.; Holder, J.W.; Muszewska, A.; Goldberg, J.; Bailão, A.M.; Brigido, M.M.; da Silva Ferreira, M.E.; Garcia, A.M.; Grynberg, M.; et al. Comparative genomic analysis of human fungal pathogens causing paracoccidioidomycosis. PLoS Genet. 2011, 7, e1002345. [CrossRef] [PubMed]

170. Rusche, L.N.; Rine, J. Switching the mechanism of mating type switching: A domesticated transposase supplants a domesticated homing endonuclease. Genes Dev. 2010, 24, 10-14. [CrossRef] [PubMed]

171. Daboussi, M.J. Fungal transposable elements and genome evolution. Genetica 1997, 100, 253-260. [CrossRef] [PubMed]

172. Moyle, L.C.; Muir, C.D.; Han, M.V.; Hahn, M.W. The contribution of gene movement to the "two rules of speciation. "Evolution 2010, 64, 1541-1557. [CrossRef] [PubMed]

173. Laurie, C.C. The weaker sex is heterogametic: 75 years of Haldane's rule. Genetics 1997, 147, 937-951. [PubMed]

174. Kondo, K.; Yamamoto, M.; Matton, D.P.; Sato, T.; Hirai, M.; Norioka, S.; Hattori, T.; Kowyama, Y. Cultivated tomato has defects in both S-RNase and, HT genes required for stylar function of self-incompatibility. Plant J. 2002, 29, 627-636. [CrossRef] [PubMed]

175. Wright, S.I.; Kalisz, S.; Slotte, T. Evolutionary consequences of self-fertilization in plants. Proc. R. Soc. B Biol. Sci. 2013, 280, 1-10. [CrossRef] [PubMed]

176. Goldberg, E.E.; Kohn, J.R.; Lande, R.; Robertson, K.A.; Smith, S.A.; Igić, B. Species selection maintains self-incompatibility. Science 2010, 330, 493-495. [CrossRef] [PubMed]

177. Pinheiro, F.; Cafasso, D.; Cozzolino, S.; Scopece, G. Transitions between self-compatibility and self-incompatibility and the evolution of reproductive isolation in the large and diverse tropical genus Dendrobium (Orchidaceae). Ann. Bot. 2015, 116, 457-467. [CrossRef] [PubMed]

178. Rabosky, D.L.; McCune, A.R. Reinventing species selection with molecular phylogenies. Trends Ecol. Evol. 2010, 25, 68-74. [CrossRef] [PubMed]

179. Rabosky, D.L. Ecological limits and diversification rate: Alternative paradigms to explain the variation in species richness among clades and regions. Ecol. Lett. 2009, 12, 735-743. [CrossRef] [PubMed]

180. Jablonski, D. Species selection: Theory and data. Annu. Rev. Ecol. Evol. Syst. 2008, 39, 501-524. [CrossRef]

181. Griffith, L.C.; Ejima, A. Multimodal sensory integration of courtship stimulating cues in Drosophila melanogaster: Contextual effects on chemosensory cues. Ann. N. Y. Acad. Sci. 2009, 394-398. [CrossRef] [PubMed]

182. Clowney, E.J.; Iguchi, S.; Bussell, J.J.; Scheer, E.; Ruta, V. Multimodal chemosensory circuits controlling male courtship in Drosophila. Neuron 2015, 87, 1036-1049. [CrossRef] [PubMed]

183. Ejima, A.; Griffith, L.C. Courtship initiation is stimulated by acoustic signals in Drosophila melanogaster. PLoS ONE 2008, 3, e0003246. [CrossRef] [PubMed]

184. Chung, H.; Loehlin, D.W.; Dufour, H.D.; Vacarro, K.; Millar, J.G.; Carroll, S.B. A single gene affects both ecological divergence and mate choice in Drosophila. Science 2014, 343, 1148-1151. [CrossRef] [PubMed]

185. Gershman, S.N.; Toumishey, E.; Rundle, H.D. Time flies: Time of day and social environment affect cuticular hydrocarbon sexual displays in Drosophila serrata. Proc. R. Soc. B Biol. Sci. 2014, 281, 20140821. [CrossRef] [PubMed]

186. Dembeck, L.M.; Böröczky, K.; Huang, W.; Schal, C.; Anholt, R.R.; Mackay, T.F. Genetic architecture of natural variation in cuticular hydrocarbon composition in Drosophila melanogaster. eLife 2015, 4, e09861. [CrossRef] [PubMed]

187. Jezovit, J.A.; Levine, J.D.; Schneider, J. Phylogeny, environment and sexual communication across the Drosophila genus. J. Exp. Biol. 2017, 220, 42-52. [CrossRef] [PubMed]

188. Schwander, T.; Arbuthnott, D.; Gries, R.; Gries, G.; Nosil, P.; Crespi, B.J. Hydrocarbon divergence and reproductive isolation in Timema stick insects. BMC Evol. Biol. 2013, 13. [CrossRef] [PubMed]

189. Chung, H.; Carroll, S.B. Wax, sex and the origin of species: Dual roles of insect cuticular hydrocarbons in adaptation and mating. BioEssays 2015, 37, 822-830. [CrossRef] [PubMed]

190. Marcillac, F.; Grosjean, Y.; Ferveur, J.-F. A single mutation alters production and discrimination of Drosophila sex pheromones. Proc. R. Soc. B Biol. Sci. 2005, 272, 303-309. [CrossRef] [PubMed] 
191. Quesneville, H.; Bergman, C.M.; Andrieu, O.; Autard, D.; Nouaud, D.; Ashburner, M.; Anxolabehere, D. Combined evidence annotation of transposable elements in genome sequences. PLoS Comput. Biol. 2005, 1, 166-175. [CrossRef] [PubMed]

192. von Schilcher, F. The function of pulse song and sine song in the courtship of Drosophila melanogaster. Anim. Behav. 1976, 24, 622-625. [CrossRef]

193. Kliman, R.M.; Andolfatto, P.; Coyne, J.A.; Depaulis, F.; Kreitman, M.; Berry, A.J.; McCarter, J.; Wakeley, J.; Hey, J. The population genetics of the origin and divergence of the Drosophila simulans complex species. Genetics 2000, 156, 1913-1931. [PubMed]

194. Garrigan, D.; Kingan, S.B.; Geneva, A.J.; Andolfatto, P.; Clark, A.G.; Thornton, K.R.; Presgraves, D.C. Genome sequencing reveals complex speciation in the Drosophila simulans clade. Genome Res. 2012, 22, 1499-1511. [CrossRef] [PubMed]

195. Brand, C.L.; Kingan, S.B.; Wu, L.; Garrigan, D. A selective sweep across species boundaries in Drosophila. Mol. Biol. Evol. 2013, 30, 2177-2186. [CrossRef] [PubMed]

196. Gleason, J.M.; Ritchie, M.G. Do Quantitative Trait Loci (QTL) for a courtship song difference between Drosophila simulans and D. sechellia coincide with candidate genes and intraspecific, QTL? Genetics 2004, 166, 1303-1311. [PubMed]

197. Peixoto, A.A.; Hall, J.C. Analysis of temperature-sensitive mutants reveals new genes involved in the courtship song of Drosophila. Genetics 1998, 148, 827-838. [PubMed]

198. Baack, E.; Melo, M.C.; Rieseberg, L.H.; Ortiz-Barrientos, D. The origins of reproductive isolation in plants. New Phytol. 2015, 207, 968-984. [CrossRef] [PubMed]

199. Ayala, D.; Guerrero, R.F.; Kirkpatrick, M. Reproductive isolation and local adaptation quantified for a chromosome inversion in a malaria mosquito. Evolution 2013, 67, 946-958. [CrossRef] [PubMed]

200. Rieseberg, L.H. Chromosomal rearrangements and speciation. Trends Ecol. Evol. 2001, 16, 351-358. [CrossRef]

201. Lowry, D.B.; Willis, J.H. A widespread chromosomal inversion polymorphism contributes to a major life-history transition, local adaptation, and reproductive isolation. PLoS Biol. 2010, 8, e1000500. [CrossRef] [PubMed]

202. Li, S.F.; Su, T.; Cheng, G.Q.; Wang, B.X.; Li, X.; Deng, C.L.; Gao, W.J. Chromosome evolution in connection with repetitive sequences and epigenetics in plants. Genes 2017, 8, 290. [CrossRef] [PubMed]

203. Soto, I.M.; Soto, E.M.; Carreira, V.P.; Hurtado, J.; Fanara, J.J.; Hasson, E. Geographic patterns of inversion polymorphism in the second chromosome of the cactophilic Drosophila buzzatii from Northeastern Argentina. J. Insect Sci. 2010, 10, 1-11. [CrossRef] [PubMed]

204. Fernández Iriarte, P.J.; Norry, F.M.; Hasson, E.R. Chromosomal inversions effect body size and shape in different breeding resources in Drosophila buzzatii. Heredity (Edinb.) 2003, 91, 51-59. [CrossRef] [PubMed]

205. Betran, E.; Santos, M.; Ruiz, A. Antagonistic pleiotropic effect of second-chromosome inversions on body size and early life-history traits in Drosophila buzzatii. Evolution 1998, 52, 144-154. [CrossRef] [PubMed]

206. Slotkin, R.K.; Vaughn, M.; Borges, F.; Tanurdžić, M.; Becker, J.D.; Feijó, J.A.; Martienssen, R.A. Epigenetic reprogramming and small, RNA silencing of transposable elements in pollen. Cell 2009, 136, 461-472. [CrossRef] [PubMed]

207. Lippman, Z.; Gendrel, A.V.; Black, M.; Vaughn, M.W.; Dedhia, N.; McCombie, W.R.; Lavine, K.; Mittal, V.; May, B.; Kasschau, K.D.; et al. Role of transposable elements in heterochromatin and epigenetic control. Nature 2004, 430, 471-476. [CrossRef] [PubMed]

208. Gendrel, A.V.; Lippman, Z.; Yordan, C.; Colot, V.; Martienssen, R.A. Dependence of heterochromatic histone H3 methylation patterns on the Arabidopsis gene, DDM1. Science 2002, 297, 1871-1873. [CrossRef] [PubMed]

209. Lippman, Z.; May, B.; Yordan, C.; Singer, T.; Martienssen, R. Distinct mechanisms determine transposon inheritance and methylation via small interfering RNA and histone modification. PLoS Biol. 2003, 1, e0000067. [CrossRef] [PubMed]

210. McCormick, S. Control of male gametophyte development. Plant Cell 2004, 16 (Suppl. 1), S142-S153. [CrossRef] [PubMed]

211. Kawanabe, T.; Ishikura, S.; Miyaji, N.; Sasaki, T.; Wu, L.M.; Itabashi, E.; Takada, S.; Shimizu, M.; Takasaki-Yasuda, T.; Osabe, K.; et al. Role of DNA methylation in hybrid vigor in Arabidopsis thaliana. Proc. Natl. Acad. Sci. USA 2016, 113, E6704-E6711. [CrossRef] [PubMed] 
212. Groszmann, M.; Gonzalez-Bayon, R.; Greaves, I.K.; Wang, L.; Huen, A.K.; Peacock, W.J.; Dennis, E.S. Intraspecific Arabidopsis hybrids show different patterns of heterosis despite the close relatedness of the parental genomes. Plant Physiol. 2014, 166, 265-280. [CrossRef] [PubMed]

213. Zhang, Q.; Li, Y.; Xu, T.; Srivastava, A.K.; Wang, D.; Zeng, L.; Yang, L.; He, L.; Zhang, H.; Zheng, Z.; et al. The chromatin remodeler, DDM1 promotes hybrid vigor by regulating salicylic acid metabolism. Cell Discov. 2016, 2, 16027. [CrossRef] [PubMed]

214. Rogers, S.M.; Bernatchez, L. The genetic architecture of ecological speciation and the association with signatures of selection in natural lake whitefish (Coregonus sp. Salmonidae) species pairs. Mol. Biol. Evol. 2007, 24, 1423-1438. [CrossRef] [PubMed]

215. Renaut, S.; Bernatchez, L. Transcriptome-wide signature of hybrid breakdown associated with intrinsic reproductive isolation in lake whitefish species pairs (Coregonus spp. Salmonidae). Heredity (Edinb.) 2011, 106, 1003-1011. [CrossRef] [PubMed]

216. Dion-Côté, A.M.; Renaut, S.; Normandeau, E.; Bernatchez, L. RNA-seq reveals transcriptomic shock involving transposable elements reactivation in hybrids of young lake whitefish species. Mol. Biol. Evol. 2014, 31, 1188-1199. [CrossRef] [PubMed]

217. Metcalfe, C.J.; Bulazel, K.V.; Ferreri, G.C.; Schroeder-Reiter, E.; Wanner, G.; Rens, W.; Obergfell, C.; Eldridge, M.D.; O'Neill, R.J. Genomic instability within centromeres of interspecific marsupial hybrids. Genetics 2007, 177, 2507-2517. [CrossRef] [PubMed]

218. O'Neill, R.J.; O'Neill, M.J.; Graves, J.A. Undermethylation associated with retroelement activation and chromosome remodelling in an interspecific mammalian hybrid. Nature 1998, 393, 68-72. [CrossRef] [PubMed]

219. Brideau, N.J.; Flores, H.A.; Wang, J.; Maheshwari, S.; Wang, X.U.; Barbash, D.A. Two Dobzhansky-Muller Genes interact to cause hybrid lethality in Drosophila. Science 2006, 314, 1292-1295. [CrossRef] [PubMed]

220. Phadnis, N.; Baker, E.P.; Cooper, J.C.; Frizzell, K.A.; Hsieh, E.; De La Cruz, A.F.; Shendure, J.; Kitzman, J.O.; Malik, H.S. An essential cell cycle regulation gene causes hybrid inviability in Drosophila. Science 2015, 350, 1552-1555. [CrossRef] [PubMed]

221. Cooper, J.C.; Phadnis, N. A genomic approach to identify hybrid incompatibility genes. Fly (Austin) 2016, 10, 142-148. [CrossRef] [PubMed]

222. Satyaki, P.R.; Cuykendall, T.N.; Wei, K.H.; Brideau, N.J.; Kwak, H.; Aruna, S.; Ferree, P.M.; Ji, S.; Barbash, D.A. The Hmr and Lhr hybrid incompatibility genes suppress a broad range of heterochromatic repeats. PLoS Genet. 2014, 10, e1004240. [CrossRef] [PubMed]

223. Di Giacomo, M.; Comazzetto, S.; Saini, H.; De Fazio, S.; Carrieri, C.; Morgan, M.; Vasiliauskaite, L.; Benes, V.; Enright, A.J.; O'Carroll, D. Multiple epigenetic mechanisms and the piRNA pathway enforce LINE1 silencing during adult spermatogenesis. Mol. Cell 2013, 50, 601-608. [CrossRef] [PubMed]

224. Kelleher, E.S.; Edelman, N.B.; Barbash, D.A. Drosophila Interspecific hybrids phenocopy piRNA-pathway mutants. PLoS Biol. 2012, 10, e1001428. [CrossRef] [PubMed]

225. Shpiz, S.; Ryazansky, S.; Olovnikov, I.; Abramov, Y.; Kalmykova, A. Euchromatic transposon insertions trigger production of novel Pi- and Endo-siRNAs at the target sites in the Drosophila germline. PLoS Genet. 2014, 10, e1004138. [CrossRef] [PubMed]

226. Senti, K.A.; Jurczak, D.; Sachidanandam, R.; Brennecke, J. piRNA-guided slicing of transposon transcripts enforces their transcriptional silencing via specifying the nuclear piRNA repertoire. Genes Dev. 2015, 29, 1747-1762. [CrossRef] [PubMed]

227. Rozhkov, N.V.; Hammell, M.; Hannon, G.J. Multiple roles for Piwi in silencing Drosophila transposons. Genes Dev. 2013, 27, 400-412. [CrossRef] [PubMed]

228. Erwin, A.A.; Galdos, M.A.; Wickersheim, M.L.; Harrison, C.C.; Marr, K.D.; Colicchio, J.M.; Blumenstiel, J.P. piRNAs are associated with diverse transgenerational effects on gene and transposon expression in a hybrid dysgenic syndrome of D. virilis. PLoS Genet. 2015, 11, e1005332. [CrossRef] [PubMed]

229. Bucheton, A.; Vaury, C.; Chaboissier, M.C.; Abad, P.; Pélisson, A.; Simonelig, M. I elements and the Drosophila genome. Genetica 1992, 86, 175-190. [CrossRef] [PubMed]

230. David, J.R.; Capy, P. Genetic variation of Drosophila melanogaster natural populations. Trends Genet. 1988, 4, $106-111$. [CrossRef]

231. Dorogova, N.V.; Bolobolova, E.U.; Zakharenko, L.P. Cellular aspects of gonadal atrophy in Drosophila P-M hybrid dysgenesis. Dev. Biol. 2017, 424, 105-112. [CrossRef] [PubMed] 
232. Kelleher, E.S. Reexamining the P-element invasion of Drosophila melanogaster through the lens of piRNA silencing. Genetics 2016, 203, 1513-1531. [CrossRef] [PubMed]

233. Kelleher, E.S.; Barbash, D.A. Analysis of piRNA-mediated silencing of active TEs in Drosophila melanogaster suggests limits on the evolution of host genome defense. Mol. Biol. Evol. 2013, 30, 1816-1829. [CrossRef] [PubMed]

234. Engels, W.R. Hybrid dysgenesis in Drosophila melanogaster: Rules of inheritance of female sterility. Genet. Res. 1979, 33, 219-236. [CrossRef]

235. Kofler, R.; Hill, T.; Nolte, V.; Betancourt, A.J.; Schlötterer, C. The recent invasion of natural Drosophila simulans populations by the P-element. Proc. Natl. Acad. Sci. USA 2015, 112, 6659-6663. [CrossRef] [PubMed]

236. Anxolabéhère, D.; Kidwell, M.G.; Periquet, G. Molecular characteristics of diverse populations are consistent with the hypothesis of a recent invasion of Drosophila melanogaster by mobile P elements. Mol. Biol. Evol. 1988, 5, 252-269. [PubMed]

237. Regner, L.P.; Pereira, M.S.O.; Alonso, C.E.V.; Abdelhay, E.; Valente, V.L. Genomic distribution of P elements in Drosophila willistoni and a search for their relationship with chromosomal inversions. J. Hered. 1996, 87, 191-198. [CrossRef] [PubMed]

238. Houck, M.A.; Clark, J.B.; Peterson, K.R.; Kidwell, M.G. Possible horizontal transfer of Drosophila genes by the mite Proctolaelaps regalis. Science 1991, 253, 1125-1128. [CrossRef] [PubMed]

239. Vagin, V.V.; Sigova, A.; Li, C.; Seitz, H.; Gvozdev, V.; Zamore, P.D. A distinct small RNA pathway silences selfish genetic elements in the germline. Science 2006, 313, 320-324. [CrossRef] [PubMed]

240. Brower-Toland, B.; Findley, S.D.; Jiang, L.; Liu, L.; Yin, H.; Dus, M.; Zhou, P.; Elgin, S.C.; Lin, H. Drosophila, PIWI associates with chromatin and interacts directly with, HP1a. Genes Dev. 2007, 21, 2300-2311. [CrossRef] [PubMed]

241. Aravin, A.A.; Hannon, G.J.; Brennecke, J. The Piwi-piRNA pathway provides an adaptive defense in the transposon arms race. Science 2007, 318, 761-764. [CrossRef] [PubMed]

242. Yin, H.; Lin, H. An epigenetic activation role of Piwi and a Piwi-associated piRNA in Drosophila melanogaster. Nature 2007, 450, 304-308. [CrossRef] [PubMed]

243. Lewis, S.H.; Quarles, K.A.; Yang, Y.; Tanguy, M.; Frézal, L.; Smith, S.A.; Sharma, P.P.; Cordaux, R.; Gilbert, C.; Giraud, I.; et al. Pan-arthropod analysis reveals somatic piRNAs as an ancestral defence against transposable elements. Nat. Ecol. Evol. 2017. [CrossRef]

244. Petrov, D.A.; Schutzman, J.L.; Hartl, D.L.; Lozovskaya, E.R. Diverse transposable elements are mobilized in hybrid dysgenesis in Drosophila virilis. Proc. Natl. Acad. Sci. USA 1995, 92, 8050-8054. [CrossRef] [PubMed]

245. Luo, S.; Lu, J. Silencing of transposable elements by piRNAs in Drosophila: An evolutionary perspective. Genom. Proteom. Bioinf. 2017, 15, 164-176. [CrossRef] [PubMed]

246. Josefsson, C.; Dilkes, B.; Comai, L. Parent-dependent loss of gene silencing during interspecies hybridization. Curr. Biol. 2006, 16, 1322-1328. [CrossRef] [PubMed]

247. Guo, M.; Rupe, M.A.; Yang, X.; Crasta, O.; Zinselmeier, C.; Smith, O.S.; Bowen, B. Genome-wide transcript analysis of maize hybrids: Allelic additive gene expression and yield heterosis. Theor. Appl. Genet. 2006, 113, 831-845. [CrossRef] [PubMed]

248. Pélissier, T.; Tutois, S.; Tourmente, S.; Deragon, J.M.; Picard, G. DNA regions flanking the major Arabidopsis thaliana satellite are principally enriched in Athila retroelement sequences. Genetica 1996, 97, 141-151. [CrossRef] [PubMed]

249. Pelissier, T.; Tutois, S.; Deragon, J.M.; Tourmente, S.; Genestier, S.; Picard, G. Athila, a new retroelement from Arabidopsis thaliana. Plant Mol. Biol. 1995, 29, 441-452. [CrossRef] [PubMed]

250. Gehring, M.; Bubb, K.L.; Henikoff, S. Extensive demethylation of repetitive elements during seed development underlies gene imprinting. Science 2009, 324, 1447-1451. [CrossRef] [PubMed]

251. Kashkush, K.; Feldman, M.; Levy, A.A. Transcriptional activation of retrotransposons alters the expression of adjacent genes in wheat. Nat. Genet. 2003, 33, 102-106. [CrossRef] [PubMed]

252. Haun, W.J.; Danilevskaya, O.N.; Meeley, R.B.; Springer, N.M. Disruption of imprinting by Mutator transposon insertions in the 5- proximal regions of the Zea mays Mez1 locus. Genetics 2009, 181, 1229-1237. [CrossRef] [PubMed]

253. Parisod, C.; Salmon, A.; Zerjal, T.; Tenaillon, M.; Grandbastien, M.A.; Ainouche, M. Rapid structural and epigenetic reorganization near transposable elements in hybrid and allopolyploid genomes in Spartina. New Phytol. 2009, 184, 1003-1015. [CrossRef] [PubMed] 
254. Castillo, D.M.; Moyle, L.C. Evolutionary implications of mechanistic models of TE-mediated hybrid incompatibility. Int. J. Evol. Biol. 2012, 2012, 698198. [CrossRef] [PubMed]

255. Ellstrand, N.C. Is gene flow the most important evolutionary force in plants? Am. J. Bot. 2014, 101, 737-753. [CrossRef] [PubMed]

256. Soucy, S.M.; Huang, J.; Gogarten, J.P. Horizontal gene transfer: Building the web of life. Nat. Rev. Genet. 2015, 16, 472-482. [CrossRef] [PubMed]

257. De la Cruz, F.; Davies, J. Horizontal gene transfer and the origin of species: Lessons from bacteria. Trends Microbiol. 2000, 8, 128-133. [CrossRef]

258. Thomas, C.M.; Nielsen, K.M. Mechanisms of, and barriers to, horizontal gene transfer between bacteria. Nat. Rev. Microbiol. 2005, 3, 711-721. [CrossRef] [PubMed]

259. Acuña, R.; Padilla, B.E.; Flórez-Ramos, C.P.; Rubio, J.D.; Herrera, J.C.; Benavides, P.; Lee, S.J.; Yeats, T.H.; Egan, A.N.; Doyle, J.J.; et al. Adaptive horizontal transfer of a bacterial gene to an invasive insect pest of coffee. Proc. Natl. Acad. Sci. USA 2012, 109, 4197-4202. [CrossRef] [PubMed]

260. Pauchet, Y.; Heckel, D.G. The genome of the mustard leaf beetle encodes two active xylanases originally acquired from bacteria through horizontal gene transfer. Proc. Biol. Sci. 2013, 280, 20131021. [CrossRef] [PubMed]

261. Peccoud, J.; Loiseau, V.; Cordaux, R.; Gilbert, C. Massive horizontal transfer of transposable elements in insects. Proc. Natl. Acad. Sci. USA 2017, 114, 4721-4726. [CrossRef] [PubMed]

262. El Baidouri, M.; Carpentier, M.C.; Cooke, R.; Gao, D.; Lasserre, E.; Llauro, C.; Mirouze, M.; Picault, N.; Jackson, S.A.; Panaud, O. Widespread and frequent horizontal transfers of transposable elements in plants. Genome Res. 2014, 24, 831-838. [CrossRef] [PubMed]

263. Diao, X.; Freeling, M.; Lisch, D. Horizontal transfer of a plant transposon. PLoS Biol. 2006, 4, 119-127. [CrossRef] [PubMed]

264. Roulin, A.; Piegu, B.; Fortune, P.M.; Sabot, F.; D’hont, A.; Manicacci, D.; Panaud, O. Whole genome surveys of rice, maize and sorghum reveal multiple horizontal transfers of the LTR-retrotransposon Route66 in Poaceae. BMC Evol. Biol. 2009, 9. [CrossRef] [PubMed]

265. Woodrow, P.; Pontecorvo, G.; Ciarmiello, L.F. Isolation of Ty1-copia retrotransposon in myrtle genome and development of S-SAP molecular marker. Mol. Biol. Rep. 2012, 39, 3409-3418. [CrossRef] [PubMed]

266. Wu, Y.; Jiang, T.; Sun, Y.; Wang, Z.; Guo, G.; Sun, S.; Wang, J.; Li, N.; Wang, Z.; Zhang, D.; et al. Mobilization of diverse transposable elements in rice induced by alien pollination without entailing genetic introgression. Plant Mol. Biol. Rep. 2015, 33, 1181-1191. [CrossRef]

267. Tamura, K.; Subramanian, S.; Kumar, S. Temporal patterns of fruit fly (Drosophila) evolution revealed by mutation clocks. Mol. Biol. Evol. 2004, 21, 36-44. [CrossRef] [PubMed]

268. Vershinin, A.V.; Allnutt, T.R.; Knox, M.R.; Ambrose, M.J.; Ellis, T.H. Transposable elements reveal the impact of introgression, rather than transposition, in Pisum diversity, evolution, and domestication. Mol. Biol. Evol. 2003, 20, 2067-2075. [CrossRef] [PubMed]

269. Schaack, S.; Gilbert, C.; Feschotte, C. Promiscuous DNA: Horizontal transfer of transposable elements and why it matters for eukaryotic evolution. Trends Ecol. Evol. 2010, 25, 537-546. [CrossRef] [PubMed]

270. McClintock, B. The significance of responses of the genome to challenge. Science 1984, 226, $792-801$. [CrossRef] [PubMed]

271. Wang, Z.H.; Zhang, D.; Bai, Y.; Zhang, Y.H.; Liu, Y.; Wu, Y.; Lin, X.Y.; Wen, J.W.; Xu, C.M.; Li, L.F.; et al. Genomewide variation in an introgression line of Rice-Zizania revealed by whole-genome re-sequencing. PLoS ONE 2013, 8, e0074479. [CrossRef] [PubMed]

272. Shan, X.; Liu, Z.; Dong, Z.; Wang, Y.; Chen, Y.; Lin, X.; Long, L.; Han, F.; Dong, Y.; Liu, B. Mobilization of the active MITE transposons $m$ Ping and Pong in rice by introgression from wild rice (Zizania latifolia Griseb.). Mol. Biol. Evol. 2005, 22, 976-990. [CrossRef] [PubMed]

273. Rosenzweig, B.K.; Pease, J.B.; Besansky, N.J.; Hahn, M.W. Powerful methods for detecting introgressed regions from population genomic data. Mol. Ecol. 2016, 25, 2387-2397. [CrossRef] [PubMed]

274. De Lucca, M., Jr.; Carareto, C.M.A.; Ceron, C.R. Distribution of the Bari-I transposable element in stable hybrid strains between Drosophila melanogaster and Drosophila simulans and in Brazilian populations of these species. Genet. Mol. Biol. 2007, 30, 676-680. [CrossRef]

275. Lachaise, D.; Cariou, M.L.; David, J.R.; Lemeunier, F.; Tsacas, L.; Ashburner, M. Historical biogeography of the Drosophila melanogaster species subgroup. Evol. Biol. 1988, 22, 159-225. 
276. Bock, I.R. The bipectinata complex: A study in interspecific hybridization in the genus Drosophila (Insecta: Diptera). Aust. J. Biol. Sci. 1978, 31, 197-208. [CrossRef]

277. de Campos Bicudo, H.E.M. Reproductive isolation in the saltans group of Drosophila. I. The saltans subgroup. Genetica 1973, 44, 313-329. [CrossRef]

278. de Campos Bicudo, H.E. Chromosomal polymorphism in the saltans group of Drosophila I. The saltans subgroup. Genetica 1973, 44, 520-552. [CrossRef]

279. Guerreiro, M.P. Interspecific hybridization as a genomic stressor inducing mobilization of transposable elements in Drosophila. Mob. Genet. Elem. 2014, 4, e88992. [CrossRef]

280. Silva, J.C.; Kidwell, M.G. Horizontal transfer and selection in the evolution of P elements. Mol. Biol. Evol. 2000, 17, 1542-1557. [CrossRef] [PubMed]

281. De Almeida, L.M.; Carareto, C.M.A. Multiple events of horizontal transfer of the Minos transposable element between Drosophila species. Mol. Phylogenet. Evol. 2005, 35, 583-594. [CrossRef] [PubMed]

282. Qian, Y.; Cheng, X.; Liu, Y.; Jiang, H.; Zhu, S.; Cheng, B. Reactivation of a silenced minimal Mutator transposable element system following low-energy nitrogen ion implantation in maize. Plant Cell Rep. 2010, 29, 1365-1376. [CrossRef] [PubMed]

283. Rettelbach, A.; Servedio, M.R.; Hermisson, J. Speciation in peripheral populations: Effects of drift load and mating systems. J. Evol. Biol. 2016, 29, 1073-1090. [CrossRef] [PubMed]

284. Le Rouzic, A.; Boutin, T.S.; Capy, P. Long-term evolution of transposable elements. Proc. Natl. Acad. Sci. USA 2007, 104, 19375-19380. [CrossRef] [PubMed]

285. Petrov, D.A. Mutational equilibrium model of genome size evolution. Theor. Popul. Biol. 2002, 61, 533-546. [CrossRef]

286. Oliver, M.J.; Petrov, D.; Ackerly, D.; Falkowski, P.; Schofield, O.M. The mode and tempo of genome size evolution in eukaryotes. Genome Res. 2007, 17, 594-601. [CrossRef] [PubMed]

287. Finnegan, D.J. Eukaryotic transposable elements and genome evolution. Trends Genet. 1989, 5, $103-107$. [CrossRef]

288. Leitch, I.J.; Kahandawala, I.; Suda, J.; Hanson, L.; Ingrouille, M.J.; Chase, M.W.; Fay, M.F. Genome size diversity in orchids: Consequences and evolution. Ann. Bot. 2009, 104, 469-481. [CrossRef] [PubMed]

289. Kraaijeveld, K. Genome size and species diversification. Evol. Biol. 2010, 37, 227-233. [CrossRef] [PubMed]

290. Burleigh, J.G.; Barbazuk, W.B.; Davis, J.M.; Morse, A.M.; Soltis, P.S. Exploring diversification and genome size evolution in extant gymnosperms through phylogenetic synthesis. J. Bot. 2012, 2012, 1-6. [CrossRef]

291. Knight, C.A.; Molinari, N.A.; Petrov, D.A. The large genome constraint hypothesis: Evolution, ecology and phenotype. Ann. Bot. 2005, 95, 177-190. [CrossRef] [PubMed]

292. Alfaro, M.E.; Santini, F.; Brock, C.; Alamillo, H.; Dornburg, A.; Rabosky, D.L.; Carnevale, G.; Harmon, L.J. Nine exceptional radiations plus high turnover explain species diversity in jawed vertebrates. Proc. Natl. Acad. Sci. USA 2009, 106, 13410-13414. [CrossRef] [PubMed]

293. Santini, F.; Harmon, L.J.; Carnevale, G.; Alfaro, M.E. Did genome duplication drive the origin of teleosts? A comparative study of diversification in ray-finned fishes. BMC Evol. Biol. 2009, 9. [CrossRef] [PubMed]

294. Amores, A. Zebrafish hox clusters and vertebrate genome evolution. Science 1998, 282, 1711-1714. [CrossRef] [PubMed]

295. Tank, D.C.; Eastman, J.M.; Pennell, M.W.; Soltis, P.S.; Soltis, D.E.; Hinchliff, C.E.; Brown, J.W.; Sessa, E.B.; Harmon, L.J. Nested radiations and the pulse of angiosperm diversification: Increased diversification rates often follow whole genome duplications. New Phytol. 2015, 207, 454-467. [CrossRef] [PubMed]

296. Flagel, L.E.; Wendel, J.F. Gene duplication and evolutionary novelty in plants. New Phytol. 2009, 183, 557-564. [CrossRef] [PubMed]

297. Voldoire, E.; Brunet, F.; Naville, M.; Volff, J.N.; Galiana, D. Expansion by whole genome duplication and evolution of the sox gene family in teleost fish. PLOS ONE 2017, 12, e0180936. [CrossRef] [PubMed]

298. Pasquier, J.; Braasch, I.; Batzel, P.; Cabau, C.; Montfort, J.; Nguyen, T.; Jouanno, E.; Berthelot, C.; Klopp, C.; Journot, L.; et al. Evolution of gene expression after whole-genome duplication: New insights from the spotted gar genome. J. Exp. Zool. Part B Mol. Dev. Evol. 2017, 328, 709-721. [CrossRef] [PubMed]

299. Hermansen, R.A.; Hvidsten, T.R.; Sandve, S.R.; Liberles, D.A. Extracting functional trends from whole genome duplication events using comparative genomics. Biol. Proced. Online 2016, 18. [CrossRef] [PubMed]

300. Van De Peer, Y.; Maere, S.; Meyer, A. The evolutionary significance of ancient genome duplications. Nat. Rev. Genet. 2009, 10, 725-732. [CrossRef] [PubMed] 
301. Puttick, M.N.; Clark, J.; Donoghue, P.C.J. Size is not everything: Rates of genome size evolution, not C-value, correlate with speciation in angiosperms. Proc. R. Soc. B Biol. Sci. 2015, 282, 20152289. [CrossRef] [PubMed]

302. Soltis, P.S.; Soltis, D.E. Ancient WGD events as drivers of key innovations in angiosperms. Curr. Opin. Plant Biol. 2016, 30, 159-165. [CrossRef] [PubMed]

303. Seehausen, O. African cichlid fish: A model system in adaptive radiation research. Proc. Biol. Sci. 2006, 273, $1987-1998$. [CrossRef] [PubMed]

304. Uyeda, J.C.; Zenil-Ferguson, R.; Pennell, M.W. Rethinking phylogenetic comparative methods. bioRxiv 2017. [CrossRef]

305. Hey, J. Speciation via hybrid dysgenesis: Negative evidence from the Drosophila affinis subgroup. Genetica 1988, 78, 97-103. [CrossRef]

306. Hudson, E.J.; Price, T.D. Pervasive reinforcement and the role of sexual selection in biological speciation. J. Hered. 2014, 105, 821-833. [CrossRef] [PubMed]

307. Trizzino, M.; Park, Y.; Holsbach-Beltrame, M.; Aracena, K.; Mika, K.; Caliskan, M.; Perry, G.H.; Lynch, V.J.; Brown, C.D. Transposable elements are the primary source of novelty in primate gene regulation. Genome Res. 2017, 27, 1623-1633. [CrossRef] [PubMed]

(C) 2018 by the authors. Licensee MDPI, Basel, Switzerland. This article is an open access article distributed under the terms and conditions of the Creative Commons Attribution (CC BY) license (http:/ / creativecommons.org/licenses/by/4.0/). 